\title{
The Sōka Gakkai 1968 Youth Movement: The Creation of Conviviality and Friendship in Sino- Japanese Relations
}

\author{
Anne Mette Fisker-Nielsen \\ (iD) https://orcid.org/0000-0002-7809-5842
}

\begin{abstract}
This article discusses an episode in the history of Sōka Gakkai that began as alternative youth movement under Ikeda Daisaku who came to advocate "people's diplomacy" (minkan gaikō) as a way to foster goodwill between China and Japan. Why would Sōka Gakkai, a legally constituted "religious corporation" (shūkyō hōjin) be so serious about engaging with a Communist regime that did not recognise religion? The article discusses what "religion" or "religious behaviour" means in Sōka Gakkai, and questions the usefulness of such a classification on a qualitative level. Ikeda's interpretation of Nichiren Buddhism highlights his approach to something seemingly very "unreligious"-namely, the normalisation of Sino-Japanese relations. Unlike the more traditional "reactive revolution" of protest movements that constructed politics as primarily a binary, ideological choice to achieve its aims, Ikeda prioritised finding ways to transcend that very ideology-centric, counter-politics approach. By appealing to conviviality, a sense of shared humanity and humility on the part of the Japanese towards their past history of colonialism, a new social imaginary and attitude that differed from politics of opposition between left and right entered as a historical force that continues to be promoted by Sōka Gakkai today.
\end{abstract}

Keywords: religion and politics, Daisaku Ikeda, Sōka Gakkai, Kōmeitō, Sino-Japanese relations and civil society, friendship and conviviality as politics

Fisker-Nielsen, Anne Mette. 2021. "The Sōka Gakkai 1968 Youth Movement: The Creation of Conviviality and Friendship in SinoSCiendo Japanese Relations." Vienna Journal of East Asian Studies, 13, pp. $210-256$.

https://doi.org/10.2478/vjeas-2021-0007

Submitted: 04.08.2020, accepted: 29.09.2020

This work is licensed under the Creative Commons Attribution 4.0 International License. http://creativecommons.org/licenses/by/4.0/ 


\section{Introduction}

The year 1968 may be remembered as a watershed for student protest movements both in Japan and elsewhere. Some four to five per cent of the Japanese student and youth population, estimated to be around 300,000 (Oguma 2015), displayed conspicuous disagreement with the political, social, and educational establishment through months of protests and the occupation of campuses. The idea that progressive attitudes necessarily always dominated among the protesting youths, however, has been challenged by Oguma. He shows how many youths were deceptively apolitical, engaging in endless moralistic self-negation that regarded any compromise with the perceive enemies of the establishment as a sign of ideological regression. He also found that there was a retrograde attitude towards women and minorities, with no apparent self-critique of Japan's military past yet visible (ibid.). 1968 also saw the emergence of a lesserknown youth movement that challenged the status quo in different ways. The Sōka Gakkai 創価学会 youth movement represented a different kind of critical thinking than the one by the political left. Sōka Gakkai's approach to social engagement notably differed in comparison from the "anti" politics that mobilised protesting youths by constructing a binary political Other against which to rally. Sōka Gakkai youths, while concerned with many similar issues, seemed motivated by a kind of political culture in which critiquing Japan's colonial and militarist past was central, and which took a particular reconciliatory approach towards China attempting to create spaces of commonality rather than the usual politics of condemnation.

When Ikeda Daisaku 池田大作 (b. 1928), the president of Sōka Gakkai at the time, made a public call on September 8, 1968, to normalise relations with China, it was a personal attempt to move forward the stalled Sino-Japanese relations. Rather than resorting to political ideology, however, he aimed to promote "goodwill" and "friendship." The year 1968, however, was a highly contentious time both domestically and internationally: it was highly controversial at the governmental, intermediate, and societal levels to call for Japan to recognise its colonial past and normalise its relations with China, and for China to be accepted into the international community. Thus, it was not surprising that the proposal created a spectacle when broadcast that same evening in the national news. Chinese journalists stationed in Japan, however, were struck by its potential significance, even as they felt it impossible to write about it amidst widespread public antagonism towards the perceived political Other that dominated public discourse both in Japan and China.

The episode discussed here that took place in the late 1960s includes the first Chinese Premier of the People's Republic of China, Zhōu Ēnlái 周恩来 (1898-1976), who was instrumental in seeking to connect with Sōka Gakkai after Ikeda's proposal for normalisation. Despite the highly antagonistic and dividing public discourses dominating the political reasoning of both left and right ideologies that framed political 
choices as primarily binary ones, a Buddhist organisation, legally defined as a religious body, began actively to work to improve Sino-Japanese relations in ways that continued to be significant.

The question is why act as such when this would have been considered unswervingly unwelcome by the vast majority of people in Japan. In Japan, Sōka Gakkai was then seen as the antithesis to the prerogatives and authority of the "secular" state because of Ikeda having established the political party Kömeitō 公明党 (Clean Government Party) in 1964. The Buddhist movement was commonly accused of violating the separation of church and state, and had become typically represented as an undemocratic, unwelcome "religious" voice meddling in politics. This perception became further politicised with the proposal for normalisation with China in 1968. The famous publication of Sōka Gakkai o kiru 創価学会を斬る (Cut Sōka Gakkai) by Fujiwara Hirotatsu 藤原弘達 (1921-1999) in 1969 captured a political discourse that would for the coming decades symbolically mark Sōka Gakkai as an authoritarian movement against free speech, and as both an illegitimate political and religious presence in Japanese society.

Why would then this legally defined "religious" organisation, amidst its rapidly growing presence as a Buddhist movement that advocated social and political engagement, also be interested in approaching a Communist state that did not ideologically or legally recognise its right to exist?

As this article shows, religion as a framework for analysis may not cast much light upon the historical episode under discussion. While in the post-war period Sōka Gakkai became an active defender of "freedom of religion" and "religion as something separate from the state" following wider discourses during this period (Thomas 2019). However, the idea that "religious" behaviour on a qualitative level was something separate from other social spheres is not found in Sōka Gakkai's interpretation of what constitutes Buddhist practice. At the qualitative level, we find a non-dual understanding of the dynamics of individual behaviour, thinking, and social life. This was also pertinent to the thinking of Makiguchi Tsunesaburō 牧口常三郎 (1871-1944), the founder of Sōka Gakkai in 1930, whose perception of the Japanese state and Imperial Rescript was to see the Japanese polity itself as a religious entity with the concept of the emperor's divinity as its legitimising social force. As will be discussed, "religion" was never perceived to be something qualitatively separate from personal attitudes in everyday life, even as the modern adherence to legally defined boundaries between state and religion were simultaneously advocated.

The common framing of "religion" as juxtaposed to a distinct realm of the "secular," however, as if the two presented incommensurable realms, played out in Japan as a key conceptual binary to legitimate state power in the face of Western imperial threats in the nineteenth century. As the Meiji Japanese state came to present itself as a secular polity, the arbitrary constructions of such conceptualisation points to its ide- 
ological nature (Josephson 2012; Isomae 2003; 2014; Horii 2018). The binary construction of religion and the secular, imported into Japan in the mid-nineteenth century, frames "religion" as something both incommensurable with "politics" and as a universally definable category. This in turn obscures the ideological nature of modern state formation as shown by Josephson (2012), Isomae (2003; 2014), and Horii (2018). While it is beyond the scope of this paper to discuss this in detail, what was categorised as "religious" ideas about secularity and the Japanese case by 1968 had gone through many arbitrary twists and turns (see Garon 1997), and the issue of state and religion was brought into the fore by the Fujiwara publication. Considering the highly charged political setting in the 1960s, the questions of how and why a Buddhist leader would choose to push the normative conceptual boundaries of mainstream societal discourse on state and religion by advocating the normalisation of diplomatic ties with a Communist country - which, moreover, was being alienated by most other international stakeholders and the wider public in Japan - are being explored here.

The historical episode in this article discusses a social movement that has continued, if in a minor way, to foster goodwill between China and Japan, and has proven influential particularly during times of heightened geopolitical tension. The article discusses the practice of Nichiren Buddhism as driven by Ikeda to become a movement that encompasses “people's diplomacy" (minkan gaikō 民間外交) but not in a way that promoted particular Buddhist doctrines, nor a specific Buddhist practice. Unlike the more traditional "reactive revolution" of protest movements that saw politics as binary, ideological choices to achieve social change, Ikeda began a tradition that would come to prioritise finding ways to transcend political disagreements by creating spaces of conviviality. This social imagining reveals attitudes and reasonings that differ compared to the typical politics of the opposition between left and right that otherwise dominated the public discourse.

\section{Religion, Interiority, and Politics of Commonality}

On February 14, 2018, as I was listening to the budget committee parliamentary debates broadcast live on NHK national radio in Japan, the words of the Lower House Kōmeitō member Tōyama Kiyohiko 遠山清彦 (b. 1969) caught my attention:

To continue, I'd like to talk about the Japan-China relationship. This year is the fortieth anniversary of the Japan-China Friendship Treaty. It is also the fiftieth anniversary of the historical call for China-Japan normalisation by Ikeda Daisaku, the founder of Kōmeitō and president of Sōka Gakkai International; and moreover, last year was the forty-fifth anniversary of JapanChina normalisation. I think there has been great improvement and progress in the bilateral relationships between Japan and China. I visited China four times last year and observed this personally. Especially at the seventh Japan-China exchange meeting at the end of the year [2017], 
when the secretary generals of the ruling parties Nikai and Inoue visited China, they were able to solve important issues (Tōyama 2014). ${ }^{1}$

He then went on to outline the preparations being made for a Japan-China summit, including the visit of the leader of Kōmeitō, Yamaguchi Natsuo 山口那津男 (b. 1952). Tōyama ended by urging Prime Minister Abe Shinzō 安倍晋三 (b. 1954) to intensify his efforts in this regard. Numerous political and exchange activities were already being planned across various political and civic levels between representatives of Japan and China in 2018, in which Toyama was involved, as the then chairman of the cross-party Japan-China Next Generation Committee (Nitchujisedai kōryū inkai 日中 次世代交流員会), a position he had held since the Committee's inception five years earlier. The numerous public references that were being made to Ikeda's role in the Japan-China relationship indicated that Ikeda had become a figure that no longer evoked immediate criticism for violating the separation of church and state (seikyo bunri 政教分離) — as it would have been the case in the past. In an interview a few weeks later, Tōyama told me that "not even the Japanese Communist party complained" (personal interview on March 2, 2018). Hearing Ikeda's role in Sino-Japanese relations positively mentioned in parliamentary debates highlighted the shift in public discourse that had occurred over the past two decades, during which Kōmeitō was in a coalition with the Liberal Democratic Party (LDP; Jiyū-Minshutō 自由民主 党). It indicated a general acceptance of Kōmeitō and its past endeavours towards being seen as a "normal" political party that had now moved into the mainstream.

Hardacre (2003) shows that the conceptual demarcations that created the religioussecular boundaries against which many negative perceptions of "new religions" (shinshūkyo 新宗教) could influence public opinion in Japan was a process intricately intertwined with how the media represented organisations that became constituted as "new religions" (see Thomas 2019). In the past two decades, "religion" as a sui generis category has been the object of scrutiny by critical Religious Studies in relation to Japan that found it to be a complex ideological construct based on arbitrary boundaries (Josephson 2012; Isomae 2003; 2014; Horii 2018; see also Dolce 2015). Simultaneously, "religion" has been the umbrella category by which Sōka Gakkai became a legal entity—i.e., as a "religious corporation” (shūkyō hōjin 宗教法人)—when this

\footnotetext{
1 続いて、日中関係について伺います(お話ししたいと思います)。本年は、日中平和条約締 結 四十年、また、公明党創立者池田大作創価学会名誉会長が日中国交正常化を提言されてから 五十周年といら歴史的な節目に当たります。昨年は国交正常化四十五周年といらこともあり、両 国関係は改善の基調で大きく前進したと感じております。私自身、昨年だけで四回訪中をさせて いただき、そのことを肌身で感じました。特に、年末の日中与党交流第七回会議に際して、二階、 井上両幹事長を先頭に訪中した際には、両国共に安定政権のもとで、両国間にある諸課題につ いて一つ一つ春実着実に解決していくことの重要性が共有されたと感じております。 https://kokkai.ndl.go.jp/\#/detail?minId=119605261X01120180214\&current=1 (accessed: August 10, 2020).
} 
became legally possible in 1951 . As a legal category, Sōka Gakkai also received certain protection and status in Japanese society, while it was also largely represented as controversial particularly in relation to its support for a political party.

"Religion" as a conceptual tool lacks any clear and stable meaning, argues Taira (2013: 26), who sees the binary pair of "religion-secular" as casting "religion" as an empty signifier that is "historically, socially, and culturally constructed and negotiated in various situations." Yet, this emptiness at the centre of the concept has proven highly productive as a social imaginary upon which the modern Japanese nation-state could project its legitimacy as "secular"-with the "secular" being symbolically associated with rationality and modernity, and progressive in its supposed mode of objective scientific inquiry. Many social thinkers such as Michel Foucault, Pierre Bourdieu, and Max Weber before outlined how such knowledge-production was intricately intertwined with powers of the state that were never straightforwardly "objective."

Emptiness may exist in any social category but, as indicated by the category "religion," this does not make it meaningless or simply unreal. Indeed, the term "religion" can be seen to have a ubiquitous power to affect "some human lives and societies" (Beckford 2003: 24). The academic difficulty of actually defining religion as something qualitatively separate from other social phenomena of course still remains intrinsic to social inquiry. As a response, delineating key concepts in a way that shows the contestation of meaning and discourses must be central to any analysis. Fitzgerald (2000: 106) argues that "[t]he category 'religion' should be the object, not the tool, of analysis." This was later echoed by Horii (2018) in his study of how the idea of religion plays out in contemporary Japan as largely a negative association for most people who by the same token define themselves and certain activities as non-religious (mushūkyō 無宗教).

In short, the use of "religion" and the "secular" as if they were generic, dichotomous, and stable categories obscure their ideological nature, as well as the complexity and creativity of statecraft (Horii 2018). Sōka Gakkai gives emphasis to reading Nichiren Buddhism as foremost a social practice beyond specific rituals, although the organisation faces its own issues with routinisation as now a long-established group. Nevertheless, Ikeda rejects the notion of "religious" faith as something qualitatively different from what is assumed to be "secular" affairs. It is important to understand that here Buddhist practice fundamentally relates to interiority-intention, attitude, and objective - which through daily chanting is typically experienced as an increased sense of will power and agency within daily social action. People seek to connect with others and with their own daily actions as in spaces where change happens, implanting a philosophical system as a praxis in daily life, and not as a belief in external forces to which one typically prays in Japan for everyday benefit or salvation. When Nichiren Buddhism, in Sōka Gakkai, is referred to by members as a "religion," they refer to 
this active practice of self-transformation that is experienced as elevating consciousness or life state (Fisker-Nielsen 2018). What this means in practice is necessarily always an empirical question.

Specific doctrines nevertheless pertain to a particular cosmology or view of how the world fits together-in this case according to the theory of ichinen sanzen as explained below. The theory does not contain a separation between Buddhist practice and "secular rule" principles and systems, such as the principles underpinning politics, economics, education, and art (Ikeda, Saito, and Morinaka 2003: 81). The only dissimilarity is the different perspective from which social action springs, i.e., an individual's action, thoughts, and words which are seen to be subject to a "law of cause and effect" that operates in all social arenas, including that of politics. This "law" is not seen as in any way separate from affairs in the world but rather as the very "mechanism" of the world, a logic that points to people's intentions and actions. Nichiren states in a writing often studied in Sōka Gakkai that "the Lotus Sutra explains that in the end secular matters are the entirety of Buddhism (WND-1: 1126).

Another key Nichiren text often studied in Sōka Gakkai, the Risshō Ankokuron 立 正安国論 (On Establishing the Correct Teachings for the Peace of the Land), is taken to point to the very significance of individual intention and behaviour - or mindsetregarded as central to the objective of creating a more humane world in the eyes of Sōka Gakkai. A mindset of "believing in the boundless potential of human beings as entities of the Mystic Law" (Ikeda 2012: 57) may be what embracing the principles of the Lotus Sutra means in terms of individual mindsets and behaviours. It is this focus on intention and behaviour and a transformation of consciousness that are considered central to transforming society, seen to be expressed by Nichiren 日蓮 (12221282) when he states the need to reform "the tenets that you hold in your heart" (Nichiren 1999: 25).

The human condition at this level of consciousness is seen as relevant also in geopolitics to transform mindsets that easily castigate the "Other" with whom one has no connection as separate from oneself. This was the reason why Ikeda advocated peopleto-people exchange (minkan kōryū 民間交流) to foster positive relations-even friendship, as a way to transform hostile relations. This approach is rooted in the philosophical system of ichinen sanzen 一念三千 (C. yinniàn sānqiān), or "three thousand realms in one moment of existence," which sees change as possible through a change in "life-state." As a daily practice to raise individual consciousness or life-state, this mindset was extended into an organised grassroots network with substantial support for a political party (see Fisker-Nielsen 2012; 2018). The ambiguous notion of referring to a "philosophical-praxis of the Buddhist law" as raison d'être for seeking to "connect with others" and to challenge the typical political narratives of Self and Other as binary constructs does not arguably gain much from the use of "religion" as form for explanation. 
By their very nature, political ideologies tend to lack self-reflection on how "cultural definitions of personhood as they are expressed in concrete and immediate but always culturally and socially defined relationships" (Illouz 2007: 3) are enacted. Instead, the ideal world imagined will come to justify opposition to others and legitimate a political position. It is the Othering in ideological terms that is challenged by Ikeda in the episode discussed in the next section. He challenges the ideological reasonings of politics that construct the Other in terms of moral absolutes, the kind of "pure criticism" (ibid.) that comes to be the standard for social judgement. Thinking through "moral absolutes" that in fact characterise binary left-right political ideology is often the very characteristic associated with "religion" and the reason why something perceived as "religious" is dismissed as unsuited for politics. The fear is that what is deemed religious may turn intolerant and thereby incompatible with the political realm, a realm characterised by compromise and the need for pragmatism. This paper shows that such clearly defined categorisation between "politics" and "religion" are not tenable at a qualitative level. Here Illouz's prescription of "stepping sideways," or engaging in "impure critique", which operates outside political moral absolutes (ibid.) may be illuminative to understand how Ikeda was able to "step sideways" and transcend the ideological and nationalist logics that projected justification for rejecting the Other by its sheer sense of belonging to another "imagined community" (Anderson 1983). Overcoming the intense Self-Other binary identity politics — or, as pointed out by Kohn (1994), nationalism as first and foremost a state of mind that reifies difference to justify a claimed materiality - is to challenge a logic that is built upon demarcating the Other as a "pure" opposition and therefore fair game (Fisker-Nielsen 2016). What I explore here is an attempt to challenge the hegemony of such a political logic, transcending the purity politics through resolving to create spaces of conviviality that deliberately imagined commonalities where seemingly none existed.

\section{Challenging the Predominant Attitude of Arrogance Towards China}

China and Japan are places where cultural and economic exchange, as well as migration, have occurred for two thousand years. With the nation-state project from the mid-nineteenth century onwards, what had been until then predominantly a relationship where ideas and skills entered Japan from China, was now reversed. Furthermore, a modernised military and political system around the turn of the twentieth century facilitated Japan's imperial prowess as Taiwan and Korea were annexed and a military presence established in mainland China (Duus, Myers, and Peattie 1989). Between 1896 and 1905, the struggling Qing 清 administration sent thousands of students to Japan to study Japan's modernisation (Wáng 2005: 84). At that time, Chinese students admired Japan for its display of strength against Western colonial powers (Chi 1980). Out of these Chinese students emerged some powerful future Chinese leaders (Lee 
1994), including Zhōu Ēnlái. In the post-occupation period, Zhōu consistently worked to improve Sino-Japanese relations despite many setbacks along the way. This took place despite the fact that the reversed Sino-Japanese hierarchy had made for an unprecedented new norm, in which the Japanese nation-state was established as culturally and politically superior, and military rulers in the 1930s had increased their aggressive colonialism into China.

The educator Makiguchi had throughout his career worked to reform the Japanese education system that was central to Japan's nation-state project from the Meiji Restoration (1868) onwards. When he founded Sōka Kyōiku Gakkai 創価教育学会 (Value-Creation Education Society) in 1930, together with his protégé Toda Jōsei (1900-1958) he combined his pedagogical theory of value-creation with his newly found belief in the doctrines and practice of Nichiren Buddhism. It was the educator Mitani Sokei 三谷素啓 (1878-1932), a lay leader in the Nichiren Shōshū 日連正宗, who had convinced Makiguchi to embrace faith. However, although Makiguchi converted to the Nichiren Shōshū in 1928, his view of both the teachings and the general category of "religion" was complex and marked by a number of tensions. On the one hand, he accepted the modern religious-secular division of labour that saw religion as something pertaining to the inner life while he simultaneously regarded any engagement with social realities as a subsequent outcome of the workings of conscience. Referencing Nichiren's 1260 petition to the Kamakura 鎌倉 Shogunate, the Rissho Ankokuron, Makiguchi viewed popular and officially sanctioned beliefs as fully intercepting the social order, and contested the normative "Shinto secular" consensus. In this way, he placed the emperor-related shrine Shintō on the same plane as other belief systems, while judging these to be incompatible with social prosperity. His contention led to his arrest for lèse-majesté in 1943 (Gebert 2004).

Makiguchi's reading of Nichiren Buddhist doctrine and practice further enabled him to challenge the state's diffused and complex system of "knowledge-power" that was founded on the essentially arbitrary secular-religious structure, on which Japan's polity (or kokutai 国体) rested. The idea of the emperor as a living god, which by the 1930s had become an unapproachable mystery, was a "truth" that Makiguchi saw as the ideology at the heart of legitimating political authority and arbitrarily represented as "secular" (Goulah and Gebert 2014). This political logic of emperor divinity was at the core of structuring Japanese subjectivity under the Imperial Rescript on Education and according to which Makiguchi also worked as a school teacher. By the early 1940s, Sōka Kyōiku Gakkai was under surveillance by Japan's Special Higher Police (tokkō 特高), and in 1943 Makiguchi was arrested together with some twenty leaders (Ito 2009). They were indicted as thought criminals and, in their refusal to comply with the obligatory worship of the emperor as divine, they challenged the very legitimacy of the Japanese polity. For Makiguchi this resonated with the heritage of Nichiren as “remonstrating with the sovereign" (kokushu kangyō 国主諫暁). 
Makiguchi died in prison in 1944, but his disciple Toda was released in July 1945. Toda began to reconstruct and revive the organisation through a series of Buddhist lectures. It was after attending one such lecture in 1947 and upon hearing of Toda's imprisonment for his beliefs that Ikeda Daisaku decided to become a member of the now renamed organisation, viz. Sōka Gakkai. Ikeda was well-read in Western philosophy - more than he was in Buddhist philosophy. He intuitively trusted Toda as a person who had withstood state pressure even at the risk of his own life. Ikeda would continue to champion this intellectual or doctrinal focus, coupled with a critique of Japan's military and imperial past (see Fisker-Nielsen 2018). Because of Makiguchi's and Toda's own remonstrations during the war, critiquing Japan's imperial history in China in the postwar period came across as particularly powerful and authentic to Zhōu Ēnlái, who was aware of this early Sōka Gakkai history. Thus he took note when Ikeda stated things like:

There are many countries in Asia where tragedy was inflicted by the Japanese army. Their family members were killed; their houses were looted or burnt. Their wrath, agony, and humiliation are engraved in their lives and can never be healed. However, Japanese people tend to obscure the truth. Younger generations are not interested in knowing the truth. Yet Japanese people boast about the country's economic power and are arrogant and rude to Asian people. With this kind of attitude, we cannot nurture genuine trust or friendship [...]. We can build trust only when our conscience and sincerity are communicated. Diplomatic relations between two nations start from mutual trust between people. Regardless of Japan's foreign policy, we must always value and cherish direct person to person connection with the people of China and engage in diplomacy with sincerity (cited in Kǒng and Jì 2006: 98-99). ${ }^{2}$

Ikeda's motivation to nurture friendship with China also grew out of what he had heard from his older brother, who had been sent to China as soldier (and later killed there). He told the young Ikeda about horrific atrocities committed by the Japanese military against Chinese people (Ikeda 2006). Ikeda's attitude towards Japan's colonial history was a major reason Zhōu Ēnlái took an interest in Sōka Gakkai. While many aspects of the China-Japan relationship are impossible to cover here, an issueoriented approach (Mōri and Zhāng 2004) may nevertheless capture some of the depth and detail of an overlooked aspect that played a part in the restoration of the bilateral

2 (さらに)アジアには、日本軍によって肉親が虐殺されたり、家を焼かれたり、略奪されたりした悲 惨な歴史を持つ国が多い。それは、その国の人びとにとつては、永遠に忘れることのできない、 憤怒と悲哀の屈辱として、魂に刻印されている。ところが、日本人は、その事実をあいまいにしよ うとする。また、若い世代も、その歴史を知ろうともしない。それでいて日本人は、経済力を鼻にか け、アジア諸国の人びとに傲慢で横柄な態度で接する。こんなことでは、本当の信頼も、友情も、 育つわけがない。(中略)相手が、こちらの人間としての良心、誠実さを知ってこそ、信頼が生ま れていくからです。国と国の外交といっても、すべては人間同士の信頼から始まる。だから、私た ちは、日本の国が、どういら政策をとろうが、中国の人たちとの、人間性と人間性のふれ合いをつ ねに大切にし、人間としての誠意ある外交をしていかなければならない。 
relations with China in the late 1960s. The episode also illuminates the particular approach that came to underpin the Sōka Gakkai movement for peace in Asia, namely, to seek to transform the arrogance that underpinned normative political discourses throughout Japan — an attitude of "superiority" that started earlier with China's experience of defeat to Western powers in Asia (Ijiri 1990).

Arrogance is also an emotional condition and mindset that is seen as having constituted for Nichiren a state of fundamental self-delusion that gives rise to disparagement of others in relation to a perception of self-righteousness - a mindset that leads to dehumanisation of others and potentially war. It is this state of arrogance that Nichiren referred to when he urged people to reform "the tenets you hold in your heart" (Nichiren 1999: 25). This is a perspective of sociality as consisting in an intricate relationship between the workings of the mind (including body and emotions) and social action, whether individually or at the governmental level (for how this is discussed in Sōka Gakkai, see Ikeda, Saito, and Morinaka 2003). It was this view of consciousness and social action as non-dual - the principle by which the "law" of cause and effect is seen to operate - that made Makiguchi agree that "religion" as a modern conceptualisation is about the inner realm. However, because the inner realm cannot be divorced from the supposedly "secular" society, the religion-secular binary in reality only exists at a theoretical level.

Ikeda tells how he observed his mother's reaction to being told about an American soldier in 1944 being dragged away by the military police when his plane had been shot down: "How terrible. His mother must be so very worried about him." This incident had left a deep impression on him as he observed how irrelevant it was to her whether the pilot was an enemy or not (Ikeda 2004: 21). This attitude of seeing the person beyond their social position was something that also characterised Makiguchi's career as an educator. His refusal to favour children of higher social status resulted in being dismissed by school governors on several occasions (Thomas 2019). Makiguchi's interrogation records also show how he "de-sacralised" the polity by referring to the emperor as just a normal person (ibid.). By acting to transform the "arrogance" towards China that Ikeda felt dominated Japan's approach to both the country and its people, which had grown out of a colonial history, he broke with institutionalised and politicised conventions and sensibilities.

After Japan was defeated in 1945, the USA became by far the most important cultural and political model, as well as the main trading partner of Japan (Tanaka 1991) trade with China was reduced almost to naught, as did past perceptions of Chinese cultural superiority. Trade increased again during the first half of the 1950 s, only to deteriorate later. This situation made non-governmental actors the more significant players in improving bilateral ties, either for trade or other reasons. In Japan, however, non-state groups have historically been viewed with suspicion and often met with suppression (Garon 1997; Hirata 2002; Pekannen 2004). NGOs, political parties, and other associations were suspected of concealing Chinese spies and often harassed 
(Vyas 2011); exchanges dropped due to suspicion of foreign influence and espionage by the Chinese authorities (Iriye 1996). Furthermore, the time when Ikeda and Sōka Gakkai became significant - in terms of the China-Japan relations (the late 1960s) was characterised by increased international tension and apprehension over the Chinese Cultural Revolution, which witnessed even the Japan-China Friendship Association (JCFA), established in 1963 at the initiative of Zhōu Ēnlái, withdraw from contact with China.

Sōka Gakkai was often perceived as a controversial religious organisation due to its rapid growth and vehement proselytising in the 1950s that also gave rise to political influence in the 1960s (see Palmer 1971). ${ }^{3}$ Its growth sometimes rested on debating with and refuting other Buddhist groups' doctrines, a practice seen as not befitting the mainstream ideology of Japanese "harmony." But what was seen as its most controversial undertaking was the establishment of a political party, Kōmeitō, which went on to become the third largest party in the Lower House election of 1967, gaining significant influence (ibid.: 84-86).

Central to the perception of the controversy was its critical stance on Japan's past militarism and imperialism, and its advocacy for normalising ties with China. Given the wider background, it is not surprising that Ikeda's public call for Sino-Japanese normalisation in 1968 would incur a hostile reception. This included protests from right-wing nationalist groups (ibid.). Forty years later, as indicated by Tōyama's parliamentary speech in 2018, Kōmeitō had become the party with long historical and diplomatic links to Chinese leaders. Sōka Gakkai also continued as a major actor in semi-governmental organisations, such as the China-Japan Friendship Association (CJFA) (Chūnichi yūkō kyōkai 中日友好協会), and the Chinese People's Association for Friendship with Foreign Countries (CPAFFC) (Zhōngguó rénmín duiwài yǒuhăo xiéhui 中国人民対外友好協会).

The next section explores why a major Chinese leader would seek co-operation with a Buddhist group when 1) its political ideology did not recognise "religion," and 2) Sōka Gakkai was conceived as a controversial religious group by mainstream society. Why did Premier Zhōu cultivate a growing interest in this rapidly expanding Buddhist movement and why would Kōmeitō as a newly established, small political

\footnotetext{
${ }^{3}$ Palmer (1971: 85) argues that the influence of Kōmeitō grew and made its presence felt at all levels of government which in return saw the older "political parties regularly rail against Kōmeitō through verbal diatribes and printed propaganda. Commonly, they single out Kōmeitō's undemocratic tendencies and sometimes even go so far as to label it a fascist political party." He goes on to show how also the Japan Buddhist Federation (Zen Nihon bukkyōkai 全日本仏教会) "has waged active political campaigns against Kōmeitō by supporting Liberal Democratic candidates" (ibid. 86). However, "the most common form of opposition has been in the press [...]. [s]ome of this printed matter is sensational and violently anti-Kōmeitō. Some, however, is written with the intent to objectively appraise Kōmeitō" (ibid.).
} 
party, accused of transgressing the constitutionally imposed boundary of the separation of religion and state, came to play a central role in the negotiation process for normalisation in 1972? The effect of this history, as indicated by Tōyama, was also the reason the Kōmeitō leader Yamaguchi Natsuo was sent to China in February 2013 as the envoy of the Japanese government amidst the Senkaku 尖閣 (C. Diàoyú 钓鱼) Islands tension.

\section{Stalling Sino-Japanese Relations in the Wake of the 2012 Territorial Disputes}

Japan-China relations entered a new stage of geopolitical tension as the disputes over the Senkaku/Diàoyú Islands rose into prominence again in 2012 (Togo 2012; Buhk 2020) just as Japan and China were to celebrate the fortieth anniversary of normalisation. The islets are located in the East China Sea and under the jurisdiction of Okinawa prefecture, an area that itself exists in an uneasy relationship with Japan (Matsumura 2015). The continuous territorial argument over sovereignty follows extensive details of ancient maps. China regards the Diàoyú Islands as inherently Chinese territory, and Japanese claims, although based upon international law, for China symbolise Japan's annexation of Taiwan in 1895 (Togo 2012; Buhk 2020). Thus, whereas these small uninhabited islets are under Japanese jurisdiction they are claimed by both China and Taiwan, and claims about them play into historical memory to reshape a discourse of revisionism (Koide 2014). There has been an increasing participation by right-wing politicians spanning both major parties, the LDP and the then Democratic Party of Japan (DPJ; Minshutō 民主党), and support for political groups such as the Nippon Kaigi 日本会議 (Japan Conference), a group connected to Jinja Honchō 神社本庁, the Association for Shintō Shrines. The revisionist discourse expresses outrage at China's claim that Japan has insufficiently admitted and apologised for its military aggression in China in the 1930s and 1940s.

When Japan officially renounced possession of Taiwan in 1951, the islands came under US administration until Okinawa reverted back to Japan in 1972. Until 2012, the Japanese government maintained a policy of not consolidating its control by refraining from building on the islands or near them. Tension erupted in 2010, and again in April 2012, when the then Tōkyō Governor Ishihara Shintarō 石原慎太郎 (b. 1932) proposed to use public funds to buy the islands. To solve the tensions created by this proposal, the then DPJ government (2009-2012) purchased the islands, effectively nationalising the territory. Huge anti-Japan protest erupted across China. As protesters destroyed Japanese businesses and goods, hostile Japanese counterparts emerged on the streets of Tōkyō to voice their anti-Chinese stance. Opinion polls repeatedly showed that as many as ninety per cent of the public in each country was negatively disposed towards the other. In China, World War II movies depicting the brutality of 
Japanese soldiers appeared frequently on TV, and social media were filled with hostile expressions towards Japan, while some Chinese military officers openly expressed confidence that in the event of conflict, China would win. Few open expressions of hostility towards China found their way into mainstream TV news programs in Japan, although the repeated showing of Chinese ships and planes threatening to land on the islands likely contributed to stirring up anti-Chinese sentiments as frequently expressed on social media, as did media pictures of a Chinese public attacking Japanese people and goods in China. This escalation of antagonism came at the time of the China-Japan fortieth anniversary of normalisation. All official celebrations were cancelled as social tension increased. Subsequently, both in the November Tōkyō Election and the general election in December 2012, nationalistic politicians striving to show their ability to protect Japan emerged.

Witnessing the hostility on the streets of Tōkyō, in the media and in the blogosphere, the contrast in the world of Sōka Gakkai was striking, and the many planned commemorative events with the CJFA took place.

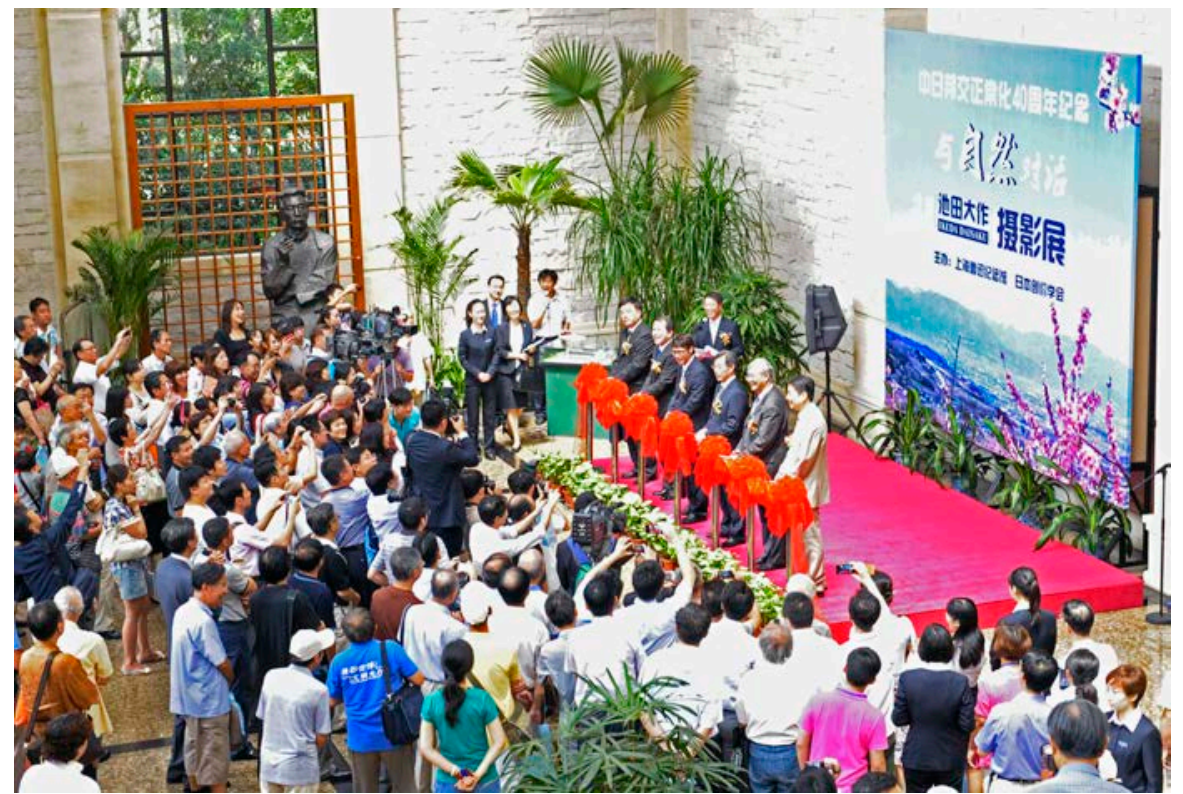

Figure 1: "Dialogue with Nature" photographic exhibition by Ikeda Daisaku, held in conjunction with the celebration of the fortieth anniversary. Lŭ Xùn 魯迅 Memorial Hall, Shànghăi, August 2012 (Copyright permission received by Sōka Gakkai).

Beyond the official events a different attitude was also prevalent, in which Sōka Gakkai leaders were found making speeches that emphasised the forty-year history of friendship, criticising the myopic nationalist attitude towards China witnessed in the public sphere. As revealed to me through first-hand research carried out in the summer 
and autumn of 2012 in Tōkyō, this attitude was to be found at all levels of the Sōka Gakkai membership. Whereas members expressed disagreement with the vandalism and violence witnessed in protests against Japan in China, they refused to follow popular sentiments that lumped people into generalised, binary nationalist constructions of "the Chinese" against "the Japanese." Rather a conscious effort to combat the predominantly negative opinions expressed about "China" or "the Chinese" could be found among Sōka Gakkai grassroots members, many of whom said that they had Chinese friends. They were clearly aware of the Sōka Gakkai's four decades of bilateral effort that had been put into transcending nationalist discourses and binary identity politics of "us" versus "them." Members were seen to remind each other of the values of human equality and dignity that they saw represented by the three presidents of Sōka Gakkai. During this period, I met with one of the Sōka Gakkai members, Kimura-san (not his real name), at one of the many smaller group meetings I attended as part of my fieldwork conducted in several areas of Tōkyō. Kimura-san's words sum up the general sentiment:

\footnotetext{
We are first and foremost human; it is essential that we transform the anachronistic way of confining ourselves to being either "Japanese" or "Chinese." This way of thinking is what caused such serious trouble in the past [referring to the Japanese invasion of China and Japanese militarism]. We live together in one world and need to show commitment to the good for all and for future generations. ${ }^{4}$
}

Maintaining this as a personal standpoint was one thing, but members also directly questioned local Kōmeitō politicians about the party's public statement at the time: that the issue could simply be solved by referring to international law, which seemed an insufficient approach given this was not simply a legal issue.

The attitude expressed at the many group discussions I attended during this period certainly could be said to express a particular ethical order that involved a community of certain values and standards in line with Durkheim's analysis of "culture" as a moral order. However, unlike the "moral order" of the nationalist discourses constructed through sharply demarcated Self-Other binaries, this "moral order" was not bounded by exclusivity or definitions of materiality. Instead, it was linked to an awareness of the complexity of such a national contestation and the idea that change is always possible, nothing is fixed nor one-dimensional, as postulated by the theory of ichinen sanzen. In this way, their attitudes challenged the idea of the "sanctity of the state" and "the controlling power of erroneous myth that the state is worthy of the highest esteem," to use Ikeda's own words (Ikeda 1974). Challenges to the national

4 私たちは何よりもまず人間です。「日本人」または「中国人」といら私たち自身を閉じ込める時代 錯誤な考え方を変えていくことが大切です。この考え方が、過去に深刻な問題を引き起こしまし た。(中国の日本の侵略と日本の軍国主義を指す)。私たちは 1 つの世界に共存しており、す心゙ ての人々と将来の世代のために善への取り組みを示す必要があります。 
myth of the imagined community indeed seemed to infuse the attitude of many Sōka Gakkai members, who expressed the idea that human "dignity is being crushed for the sake of states" (ibid.).

This attitude of "transcending the emotional pull of national belonging" was expressed practically in organised politics in the form of their support for Kōmeitō, and specifically their own involvement as Sōka Gakkai members who supported cultural events and exchanges with Chinese counterparts. Some five months later, after the LDP-Kōmeitō coalition had returned to power in December 2012, it came as no surprise to them that it was a Kōmeitō representative who would step in to ease the geopolitical tension between Japan and China. The significance of institutionalising a history of "good will" and "friendship" helped to transform some of the dominant Japanese antagonism towards China. Whereas nothing was mentioned in the news regarding the history discussed here, a newspaper reported under the title "Japan's Abe sends peace envoy to China": "While he [Yamaguchi] has no official role in the Tōkyō government headed by the hawkish Mr Abe, the occasion was a rare positive step as the territorial dispute weighs heavily on relations between the two Asian giants" (AFP with Bloomberg 2013).

\section{Beyond Politics? Youth Relations Advocated as Key to Peace in Asia}

A generalised analysis of China-Japan relations covers naturally numerous untold gaps, as pointed out by Saionji Kazuteru 西園寺一晃 in his book Zhōu Énlái to Ikeda Daisaku no ichigo Ichie 周恩来と池田大作の一期一会 (The Meeting Between Zhōu Ēnlái and Ikeda Daisaku), which came out in 2012 to coincide with the fortieth anniversary of normalisation. During the period of 1949-1972, which ended with the Japan-China normalisation treaty, Saionji was a young man living in China (from 1958 to 1968). His father, Saionji Kinkazu 西園寺公一(1906-1993), was a business man who was also a well-known unofficial Japanese ambassador to China. The Saionji family was close to Zhōu Ēnlái and his wife Dèng Yǐngchāo 邓颖超 (1904-1992), who both personally looked after Kazuteru. The trust Zhōu placed in Ikeda during this process of normalisation, Saionji observes, contributed to a more rapid resolution towards normalisation than would have been the case if such a relationship of trust had not been built (personal interview on July 2, 2015). However, there were various people involved to persuade the Chinese Premier to take notice of Ikeda and the Sōka Gakkai.

With the San Francisco Peace Treaty coming into effect in 1952, the Japanese government signed a peace treaty in April of that year with the nationalist Kuomintang government of Taiwan, or the Republic of China (ROC). This resulted in a pivotal breach between Japan and mainland China. While the Japanese government did not recognise the People's Republic of China (PRC) and the Communist Party as the 
rightful government, Premier Zhōu continued to seek to foster nongovernmental relations and economic exchanges between government officials and business leaders in both countries. This resulted in a private trade agreement in June. Despite the heightened tension over the Korean War, in the first half of the 1950s, Sino-Japanese relations only had semi-government access channels that were created through the establishment of trade organisations in both China and Japan. Various anti-China and antiCommunist sentiments emerged and subsided in Japan with each changing prime minister (see Jain 1981; Takemine 2006). This made constructing and maintaining bilateral relations the responsibility of non-governmental actors (Vyas 2011). On the Chinese side, organisations involved in exchange were connected to the Chinese government or the Communist Party, such as the China Committee for the Promotion of International Trade (est. 1952) and earlier the CJFA (est. 1950).

Zhōu was instrumental in creating communication and trade channels and seems to have maintained the position that most Japanese people had themselves been victims of the ideology of Japanese militarism (Saionji 2012a: 76-77). He thereby avoided taking a blanket anti-Japan approach. Zhōu was also instrumental in bringing about the repatriation of Japanese nationals, which particularly affected women and children abandoned in China after the war by the Japanese government (see Chan 2011). In 1953, the Japanese Red Cross Society (Nippon sekiju jisha 日本赤十学社) and its Chinese counterpart, the Red Cross Society of China (Zhōngguó hóng shí xuéhui 中国紅十学会), arranged for the return of 40,000 Japanese who had been stranded in China after the war. They also arranged for the return of the remains of thousands of Chinese who had died in Japan (Katagiri 1995). This was despite, as Dower (1999: 272) has shown, the Red Purge involving "close collaboration among occupation officials, conservative politicians, governmental bureaucrats, and cooperate managers," in which many private corporations played an active role with the backing of the Supreme Commander for the Allied Powers (SCAP) (Dower and Hirata 2007). Hofmann (2020: 414) has recently demonstrated how "anti-communism was not just ideological [... but] also social-interactionist. [...] [W]ith its deep roots in Japanese society, anti-communism operated as an enabling idea that reinstated networks severed by the war and, in so doing, helped to shape the basis of postwar elite political culture."

When the Hatoyama 鳩山 administration (1954-1956) established contact with the USSR in 1956, expectations rose that Japan's relations with China would improve. However, Kishi Nobusuke 岸信介 (1896-1987), who was backed by pro-Taiwan political factions in Japan, was about to take office in February 1957. Kishi pursued a particularly hostile policy towards China, repeatedly making anti-communist and antiChinese statements in public, making clear that he would welcome Kuomintang's recovery of mainland China. Wider anti-Japanese sentiments in China and anti-Chinese sentiments in Japan ran high. At a Chinese stamp fair at a Nagasaki department store in May 1958, a right-wing Japanese youth removed a PRC flag. The police refused to 
respond, and, since the Japanese government did not recognise the PRC, it did not allow the Chinese resident trade missions to raise the Chinese national flag again (Soeya 1996). The Nagasaki Flag Incident prompted China to halt all economic transactions with Japan and protests broke out in China against the Kishi government. This proved a severe blow to Chinese restaurants in Japan and other small businesses that relied on raw materials from China, such as lacquer.

Zhōu was known for his diplomatic skills, strength of character, while seemingly being a much-loved person amidst extreme Maoist policies. However, both who he was and the actions he took in light of his complicated life as second in charge to Máo Zédōng 毛泽东 (1893-1976) are difficult to assess as he was both complex and contradictory (Spence 2009) as shown in Gao Wenquien's biography of Zhōu (2008). From Saionji, however, we get a different account of Zhōu, who continued to foster Sino-Japanese relations and personally initiated "people-to-people diplomacy" that became the hallmark of the later CJFA (Saionji 2012a: 73). During this time, the Japanese Diet member Matsumura Kenzō 松村謙三 (1883-1971) also worked to improve China-Japan relations. As someone who had studied Chinese and held a number of official ministerial posts, he was invited by Zhou to visit China during the time relations were deteriorated in 1959 . He spent over forty days travelling throughout the country and met with Zhōu on four occasions. At one such meeting Matsumura suggested to contact Takasaki Tatsunosuke 高碕達之助 (1885-1964), whom Zhōu also knew being one of the Japanese representatives at the Asian-African conference in 1955 held in Bandung, Indonesia (Tsang 1994).

Takasaki was a Kansai business leader and director general of the Economic Planning Agency (1954-1956) under the Hatayama administration, and later became the minister of international trade and industry (1958-1959) under Kishi. Despite politically deteriorating relations under Kishi, Takasaki and Zhōu continued their exchanges, which led to the normalisation of trade in 1962. It was around this time that Zhōu started to take Sōka Gakkai and its leader Ikeda into account in his attempt to normalise Sino-Japanese relations. Both Matsumura and Takasaki urged him to befriend the organisation (Kŏng and Jì 2006: 38). Takasaki lived close to the Sōka Gakkai headquarters and observed many socially active members there. He was aware that Ikeda advocated a United Nations recognition of the PRC. Zhōu became interested in the organisation's rapid growth and energy, which he believed would be unsustainable had it not had the support of a large number of ordinary people (cited in Kŏng and Jì 2006: 26). Moreover, under Ikeda's leadership, Sōka Gakkai advocated friendship with China as a motion for peace (ibid.). Zhōu initiated a study of Sōka Gakkai by the Chinese government. Through this initial report the top Chinese leadership learned how Makiguchi and Toda had been persecuted by the Japanese military government.

The initial report on Sōka Gakkai presented to the Chinese leadership also included views upheld by some in Japan that Sōka Gakkai aimed to re-militarise Japan. This 
was perhaps what urged Premier Zhōu to instruct the Chinese People's Institute of Foreign Affairs (Zhōngguó rénmín wàijiāo xuéhuì 中国人民外交学会) to conduct a more thorough study of the organisation. As a result five individuals from the Japan Office of the Chinese Institute of Foreign Affairs, including Jīn Sūchéng 金蘇城 and Huáng Shìmíng 黄世明 (1934-2003), launched a research that was published in 1963 in the World Affairs Press (Sekai chishiki shuppansha 世界知識出版社) under the title Sōka Gakkai - Nihon no shinkō shūkyō teki seiji dantai 創価学会-日本の新興 宗教的政治団体 (The Sōka Gakkai: A New Religious Political Organisation). "Through our research, we learned that the Sōka Gakkai was an organisation committed to ordinary people and to promoting Sino-Japanese friendship. Premier Zhōu contemplated for quite some time how he could establish relations with Sōka Gakkai" says Lín Liyùn 林麗喡 (b. 1933), who worked closely with Zhōu (cited in Kŏng and Jì 2006: 48).

When Takasaki first met with Ikeda in September 1963 he asked him to work for friendship between the two countries, to which Ikeda agreed. The following month, the Běijīng government established the China-Japan Friendship Association (CPFA) and in April 1964, the Liáo Chéngzhì 廖承志-Takasaki, or L-T Memorandum was finalised. At Kōmeitō's inauguration in November of that year, Ikeda made one request to the party, namely that its foreign policy would adopt formal recognition of China and restore Sino-Japanese bilateral relations. However, despite initial progress, bilateral relations worsened again when Satō Eisaku 佐藤榮作 (1901-1975) became prime minister in November just when the United States involvement in the Vietnam War was to escalate. Satō's policy was to contain Communism, prioritise Japan's relations with the Republic of China or Taiwan, and adopt the so-called "Yoshida Letter," which was written by the former Prime Minister Yoshida Shigeru 吉田茂 (18781967; in office: 1949-1953) to the chief secretary of the Chiang Kai-shek (Jiăng Jièshí 蒋介石; 1887-1975) government. He prohibited the Export-Import Bank to continue financing exports to the PRC; with all major trade halted, a substantial setback in relations with China occurred. Matsumura Kenzō attempted to rally support within the ruling LDP in opposition to the Satō faction, but those who sought Sino-Japanese friendship were in a minority.

Coupled with Satō's hard-line stance towards China, the Cultural Revolution that erupted in 1966 caused internal confusion and gave rise to the extreme radical left opposing the party leaders of the more moderate side. The extremity of the Cultural Revolution also worsened China's relations with the developing countries that had flourished since the Bandung Conference. China found itself in a state of increasing international isolation. Even those who had promoted bilateral relations with China hesitated to continue to do so (personal interview with Saionji July 2, 2015). The fatal stabbing of the Socialist Party leader Asanuma Inejirō 浅沼稲次郎 (1898-1960) in October 1960 by a right-wing Japanese youth for his advocacy of socialism and support for the Chinese Communist Party (CCP) and for Máo Zédōng's policies had 
shown that advocating Sino-Japanese friendship was not to be taken lightly. There were companies who fired people for advocating friendly relations with China and people who divorced their spouses on those grounds (ibid.; Miyake 1994).

The JCFA, which had been important at the beginning of the 1960s, faced its own internal conflict between its two main factions, the Japanese Communist Party (JCP; Nihon kyōsantō 日本共産党) and the Japanese Socialist Party (JSP; Nihon shakaitō 日本社会党). The struggle was over whether to lend support to the USSR, advocated by the JCP sympathisers, or to China, the position of half or more of the JSP supporters. The JCP split with the CCP in 1966 over disagreement with Maoist policies. The disagreement stalled the activities of the JCFA (Kuriyama 1976). The JCP was influential enough to stop a planned exchange of 800 Japanese youth to China in 1966. Eventually the JCFA split into two groups later that year, with largely JSP sympathisers vowing to continue exchanges with the PRC, whereas JCP sympathisers refused to do so. Thus, the Cultural Revolution greatly affected the JCFA, and this internal conflict over how to approach China was felt across its regional branches (Vyas 2011: 144). The Sino-Japanese relations thus entered their most difficult phase, and the JCFA only became affective again after normalisation in 1972, with many other organisations also rushing to befriend China thereafter (ibid.: 140-141).

Hence, very few people were willing to engage with China during the latter part of the 1960s. Ariyoshi Sawako 有吉佐和子 (1931-1984) was an exception. As a popular novelist and one of Japan's most famous female writers, Ariyoshi was advocating change in social values in domestic life and protection of the environment among other social issues. She was also engaged in a dialogue with Ikeda that was being published in a women's magazine. Having spent time in China, Ariyoshi knew both Máo Zédōng and Zhōu Ēnlái personally. She advocated to the Chinese leaders to meet with Sōka Gakkai. As Liú Déyǒu 刘德有 (b. 1937), a reporter from the Guāngmíng Ribào 光明日报 (Guāngmíng Daily) at the time, informs: “One day, I met Ms. Sawako Ariyoshi, a renowned Japanese author. To my surprise, she told me about the Sōka Gakkai saying 'In Japan, there is a serious-minded organisation called the Sōka Gakkai. There are many young people in the organisation who are honest and earnest. Would you be interested in meeting them?'” (cited in Kŏng and Jì 2006: 49). ${ }^{5}$ Accompanied by the editor of the women's magazine, Ariyoshi met Ikeda in May 1966. It was then that she informed him that the Chinese leader had a strong interest in contacting Sōka Gakkai. She extended an invitation from Zhōu Ēnlái to Ikeda to visit China. In the summer of 1966, she arranged a meeting between the head of the Chi-

\footnotetext{
5「ある時、私は日本の著名な女流作家・有吉佐和子氏に会ったが、彼女は意外にも私に創価 学会のことを話した」。(有吉佐和子氏は)「日本には創価学会といら大変まじめな団体があり、こ の団体には多くの青年がいて、彼らは誠実で、まじめである。彼らとお会いになってみませんか」 と言ったと記している。
} 
nese trade liaison office in Japan, Sūn Pínghuà 孫平化 (who was to become an influential member of the Chinese Communist Party), Liú Déyǒu, and Sōka Gakkai representatives, as reported by Liú Déyǒu, who was present as a journalist having been stationed in Japan after the 1964 Memorandum Agreement that facilitated an exchange of journalist and trade between the two countries.

Meanwhile, Prime Minister Satō increasingly displayed public antagonism towards China. In 1967, Japan and the United States issued a joint statement adopting a hard-line stance towards China; in return, China aggressively denounced Japan. The Chinese Cultural Revolution was raging in the meantime. Power struggles between rival political factions (Spence 1999: 565) ${ }^{6}$ as well as for control over direction and policies of China were ongoing, while numerous atrocities were being committed by the extreme radical left. In August 1967, Chinese demonstrators broke into the embassy of the Soviet Union, and Sino-Soviet relations again deteriorated drastically. Five days later, the Red Guards laid siege to the office of the British chargé d'affaires in protest against the British government's policy towards Hong Kong. In September, the Běijīng government withdrew the press credentials of journalists from three Japanese newspapers. At the end of 1967, the L-T Memorandum trade agreement—which had been important for official negotiations - ran out, being replaced by a new accord subject to annual renewal. Saionji (2012a) points out that in 1967-1968 international relations with China were at their worst, and that 1968 was an inconceivably difficult year to be advocating the normalisation of diplomatic ties between China and Japan, something that would have attracted widespread criticism (personal interview on July 2, 2015).

While China had seen the rise of radicalised youths in the form of the Red Guards, the year of 1968 was also the height of student protest movements in Japan as indicated at the beginning of this paper. Oguma (2015) demonstrates how the movement arose as a mass response to rapid economic growth that had propelled mass migration to the urban centres. In some places as high as forty-seven per cent of this immigration were youth aged between fifteen and thirty-two years old, made up by people primarily unaffiliated with any political party. Although there was a significant minority with broader political objectives, Oguma describes most people as feeling alienated from their communities, while having to endure cramped living conditions in the city. The vast majority were males with ample time on their hands. Oguma shows that protest movements reflected an identity crisis and sense of hopelessness with decreasing job opportunities, as well as boredom. Violent clashes with the police became a form of entertainment for some. The well-known Shinjuku Riots in October 1968 was one extreme example. Alienation in the face of the felt mass anonymity in the school system and increasing mass consumption made many students feel anxious and dissatisfied. In 1966-1967, they set up the Zenkyōtō 全共闘, short for Zengaku Kyōtō Kaigi

\footnotetext{
${ }^{6}$ For the different positions on this, see Fogel 2015: 543-547.
} 
全学共闘会議 (All-Campus Joint Struggle Council)—a Marxist-inspired movement that declared its aim of overturning existing structures and their hatred for bloated consumerism (Oguma 2015: 6).

Anxiety and dissatisfaction with the university system were represented by images of students barricading campuses (some for up to six months in 1968) against police forces and in the name of academic freedom. This initially attracted sympathy from the Japanese media. From mid-1968 to early 1969, the Zenkyōtō movement spread to hundreds of campuses and thousands of high schools nation-wide. The Zenkyōtō groups initiated direct action as the way to change. Rhetorically progressive, Oguma argues, many were deceptively apolitical, inward-looking, and moralistically engaged in endless self-negation, while alternative approaches were criticised as compromised revisionism. The Zenkyōtō groups advocated Marxist theories but were themselves estranged from the JCP and other formal political parties. They operated across university campuses, advocating an anti-establishment rebellion. Behind the frustration was an increasing anxiety about their future, the devaluation in job security that diminished the significance and social status previously attached to university graduates. They protested against the Vietnam war, the Japan-US Security Treaty, and conservative governments, while also showing some sympathy for the right-wing novelist Mishima Yukio 三島由紀夫 (1925-1970; pen name of Hiraoka Kimitake 平岡公威) (ibid.). Moreover, the dominant historical narrative was that the Japanese had been victims of the Asia Pacific War with little attention paid to Japan's history of colonialism in China and elsewhere.

\section{Ikeda's 1968 Proposal for Normalisation and the Sōka Gakkai Youth Movement}

Amidst these turbulent times, why would Ikeda make normalisation of diplomatic ties with China central in a strategy for peace in Asia when such a proposition was bound to face wide social opposition and would not have resonated with many people in Japan? Furthermore, why would this appeal to several millions of young people when their counterparts in Japan advocated such different strategies to desired change? Ikeda stressed that he was not a conservative critical of the protest movements, whether in Paris or in Tōkyō, but rather saw them as " $[t]$ he revolt of the rising generation against the authority of the older [...]. [E]ven the cultural revolution [... is a] revolt against the social structure, institutions, and technology of the past" (Ikeda 1969: 33). Kōmeitō had also been established to directly deal with issues of government corruption, provision of social welfare, protection of minorities, or local environmental problems (such as the case of mercury poisoning, i.e., the Minamata disease). These issues were still to come to the attention of protesting youths (Oguma 2015) but were central to Kōmeitō and its supporters' platform. Sōka Gakkai youths 
also had begun a decade earlier a movement to abolish nuclear weapons. Yet, their approach to realise the desired change was not to protest about this in the streets. Instead, a different political culture and mindset predominated, which in the first instance related to challenging the sense of "arrogance" and self-righteousness that Ikeda saw as the prevalent attitude in the social dynamics of geopolitics, and a deep flaw in Japan's approach to China.

Student members of Sōka Gakkai began in May 1967 a study movement on campus among their protesting peers. By March 1968, there were 154 of such groups across the country. Other Sōka Gakkai youth members outside the university engaged in similar activities, inviting their peers to discuss Nichiren Buddhist doctrine in light of the social and political issues of the day. These discussions focused on principles that emphasised how a person's own behaviour and choices were part of making the kind of society they desired. The students tried to make relevant concepts such as “oneness of life and environment" (eshō funi 依正不二) and “oneness of mind and body" (shikishin funi 色心不二), as well as the concept of ichinen sanzen, which encompasses these ideas. The notion of yinniàn sānqiān was developed by Tiāntāi's 天 台 (J. Tendai) founder Zhìy 智顗 (538-597; J. Chigi), who systematised from the Lotus Sütra the theory of "three thousand realms" (sanzen 三千) in "one thoughtmoment" (ichinen 一念). Through this they advocated inner change in mindset as intricately linked to social change. It was upon this theory that the chanting of Nam $[u] M y \bar{o} h \bar{o}$ Renge Kyō 南無妙法蓮華經 to the Gohonzon 御本尊 as the “object for observing the mind," that the idea that each moment presented an opportunity to react and act differently, was promulgated. Thus, the theory was not championing a political cause but advocated that a change in mindset is the cause of change. In the discussion groups they emphasised the power of the individual to do something to change what they did not like-but emphasising that respect for others had to be at the core, or it would be a failure as this easily resorts to disparagement of others, the opposite of what Buddhist practice meant. Developing inner self-confidence was seen as key to self-empowerment, whereby understanding how individual mindsets and actions function matters in constructing what "society" becomes. A sense of hopelessness and anxiety may have been equally felt among the Sōka Gakkai youths, similar to those students who took to the streets to protest, but they approached such anxieties and disagreements differently and notably also with a commitment to representational politics through support for Kōmeitō as the route to wider structural change. This linking of individual empowerment with social change landed Kōmeitō a huge electoral victory of forty-seven members in the parliament in its first Lower House election in 1967. 
September 1968 was an unseemly time to be calling for normalisation when the world was engaged in condemning China amidst the Cultural Revolution, and student and youth protest movements occupied the political imagination along left-right political ideologies. This was not the first time Ikeda discussed China and Japan's colonial history, or advocated for the People's Republic of China to enter the United Nations. As mentioned, this was Kōmeitō's foreign policy platform since its inception in 1964, so it probably did not come as a great surprise to the almost 20,000 Sōka Gakkai student representatives (out of a reported 230,000 student division members in Sōka Gakkai at the time) present that day in a civic hall in Tōkyō. Nevertheless, in the hour long address, Ikeda's public appeal for the "China problem" to be solved by accepting the country as a full-fledged member of the international community must have seemed somewhat of a far-fetched objective.

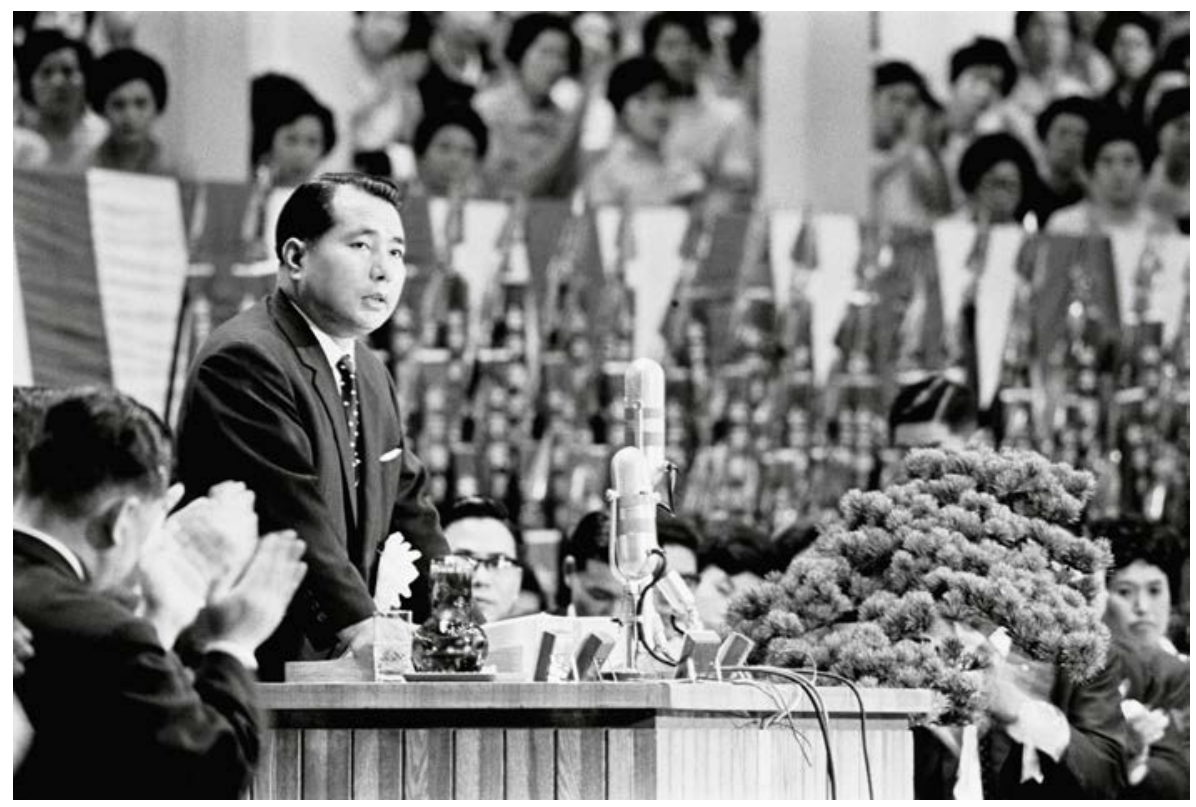

Figure 2: Ikeda Daisaku delivering the speech on September 8, 1968 (Copyright permission received by Sōka Gakkai).

Ikeda argued that China must acquire fair and equal status in order to develop peace in Asia, starting with a formal recognition of the Chinese government and a proper seat at the United Nations, which would enable China to participate in international forums. He stated that it should have been natural for the Japanese government to advocate this, given the two countries' close historical traditions and ethnic origins, and of course geography; meanwhile, Japan should refrain from sheltering under the American nuclear umbrella. Additionally, he argued that new treaties were insufficient: peace in Asia would only be possible when young people from China and Japan 
would work together for a brighter future. The above points were not made as an admirer of Communism, as he stressed, but because without friendship that crossed borders and a failure to act amidst the threat of destruction by the nuclear age could have disastrous results. Furthermore, one should not forget that poverty and inequality were the fundamental causes of instability and had to be rectified. ${ }^{7}$

He then called for immediate talks to take place between the leaders of China and Japan to facilitate the normalisation of relations, criticising the Japanese government for assuming that with the signing of the 1952 ROC Treaty the issue of peace between China and Japan would be resolved.

This stance however is nothing more than an unrealistic view which effectively ignores the existence of the 710 million people living on the continent in mainland China. The normalisation of relations between nations will only be meaningful when the people of both come to understand each other and interact in ways that are mutually beneficial, contributing by extension to world peace. Therefore, the 710 million people of mainland China are the real subject of our relations with China (Ikeda 1968c [2013]: 35). ${ }^{8}$

This would include discussions regarding the monetary compensations for damages caused by Japan to China during the war. He also stressed the ideal of unity of all peoples and acknowledged the huge cultural debt Japan owed to Chinese civilisation, including of course the introduction of Buddhism to Japan.

Ikeda then went on to discuss the issue of Chinese representation in the United Nations, an issue that was raised at the fifth United Nations General Assembly in 1950, where the US government at first considered recognising the PRC. With the participation of the PRC Voluntary Army in the Korean War, however, this changed. Despite the continuous opposition from the US, at the twentieth General Assembly in 1965which had been a peak year of support for China - votes were equally divided on the issue. In 1968, Ikeda urged the Japanese government to take a decisive step and recognise the representation of the Běijīng government at the upcoming General Assembly. He stated: "There is no doubt that the present situation, in which a quarter of the

\footnotetext{
${ }^{7}$ Ikeda would continue to emphasise similar issues that developed more formally from 1983 into yearly peace proposals to the United Nations.

8 だが、これは大陸・中国の七億一千万民衆をまるで存在しないかのごとく無視した観念論にす ぎない。およそ国交の正常化とは、相互の国民同士が互いに理解しあい交流しあって相互の利 益を増進し、ひいては世界平和の推進に 貢献することができて、初めて意義をもつものである。 したがって、日中国交についても、その対象の実体は、中国七億一千万の 民衆にあるわけであ る。それを無視して単なる条約上の “大義名分”にこだわり、いかに筋を通したと称しても、それ はナンセンスであるといわざるをえない。(Ikeda 1968c [2013]: 49). The pagination differs from the English as a Chinese, English, and Japanese version is contained in this publication as the three versions are included in this publication.
} 
world's population is effectively excluded from the United Nations, constitutes a serious defect in that organisation" (ibid.: 38). ${ }^{9}$ The various developments and setbacks for trade relations were then discussed, urging Japan to do away with the Yoshida Letter, and uphold the three trade principles, while pointing out that trade between European nations and China had increased significantly until the beginning of the Cultural Revolution. He urged Japan to recognise the huge economic benefit related to prosperity in Asia if trade relations improved, and to recognise that poverty, as well as mistrust and confrontation between capitalist and communist countries, were the root causes of instability in Asia. In order to fundamentally uproot the problem of poverty, Japan had to recognise its responsibility through establishing friendly ties with China. In conclusion, he stressed that it is a mistake to assume that a person was "left-wing" because they advocate friendly relations with China.

This is an entirely superficial way of thinking. It is only natural for us as Buddhists [literally from the perspective of the Buddhist law], out of a commitment to humanity and the ideal of global transnationalism, to desire peace and stability for Japan and the world. Anyone who makes the effort to understand the true nature of this perspective will quickly realise that it is not constrained by the political categories of left and right. Making hasty judgments based on the superficial appearance about whether something is of the left or right is a serious error. Ultimately, the most important thing about a way of thinking is the worldview in which it is rooted. Any discussion that ignores this, is meaningless. For us, the underlying idea is the Buddhist philosophy of the unity of the physical and spiritual, the material and mental aspects of life [in Jp. non-duality of mind and body]. Our approach, that of the Middle Way, is firmly grounded in this (ibid.: 40). ${ }^{10}$

In the evening, the “Japan-China proposal” (nitchü teigen 日中提言), or “Ikeda proposal" (Ikeda teigen 池田提言) as it later became known, was covered by major Japanese newspapers including the Yomiuri Shinbun 読売新聞, Asahi Shinbun 朝日 新聞, and Mainichi Shinbun 毎日新聞.

Following his speech, the content of the "Ikeda proposal" spread around the world via various media outlets, creating great sensation. The Chinese government obtained the details of the proposal at an early stage through a report by Liú Déyǒu [...]. Premier Zhōu took particular note of the Ikeda proposal and set great store by it. Thereafter, the Premier began to take the Sōka Gakkai even more seriously. When Suganuma Masahisa ${ }^{11}$ visited China in December 1970, during his meeting with the Premier, the Premier pursued questions about the Sōka Gakkai, such as

9 およそ、地球全人口の四分の一を占める中国が、実質的に国連 から排斥されているこの現状 は、誰人が考えても国連の重要な欠陥といわねばならない。(Ikeda 1968c [2013]: 51-52).

10 なぜならば、我々が仏法といら立場にあって、人間性を根幹に、世界民族主義の次元に立っ て、世界平和と日本の安泰を願っていくことは当然である。そして、その本質をとらえていくならば、 右でもなければ、左でもないことは、明瞭に理解できると思う。現象面だけを見て、右とか左とか、 性急な論断を下すことは大きい誤りである。所詮、右、左といっても、その思考の基点は何かとい うことが大事である。それを無視して論議しても無意味である。この基点こそ色心不二の大哲理 であり、それをしっかりとふまえた行き方が、中道主義 ではないだろうか。(Ikeda et al. 2003: 54).

${ }^{11}$ On the interpretations of the Cultural Revolution, see Fogel 2015; cf. Suganama 1967. 
its distinguishing characteristics and its daily activities, for about thirty minutes (Kŏng and Jì 2006: 96). ${ }^{12}$

As Lín Lìyùn recalled, "[e]very day, the Premier was thoroughly checking news covered by the Japanese media. We were also very pleased to learn that the Soka Gakkai, one of the largest religious organisations in Japan, has at last launched a movement to promote Sino-Japanese relations" (cited in Kǒng and Jì 2006: 31). ${ }^{13}$

In Japan the "great response" took on a different turn. Widespread public criticism emerged, including street protests and even death threats from right-wing groups. "The political climate was very bad. Any association with China was frowned upon. It was a difficult time to boldly call for Sino-Japanese friendship. Indeed, issuing his proposal must have been a deadly struggle," says Saionji (interview with the author July 2, 2015). He writes:

The situation was such at the time that to be insisting on normalisation between Japan and China one needed to prepare for evacuation and attack. As a journalist, I interviewed various pro-China politicians, and they all look back at that time as "a very tough time because just to be seen as promoting friendship with China would incur attacks by right-wing groups" (Saionji 2012a: 95). ${ }^{14}$

Saionji continues to explain how it transpired and both the US and Japanese governments expressed strong dissatisfaction and concern over Ikeda's Japan-China proposal three days later, on September 11 and 12, 1968, at a Japan-US security consultative meeting that was called in Tōkyō. From declassified documents we learn that President Ikeda's statement towards China was seen as a terrible mistake and that the citizen-level diplomacy promoted by Ikeda was a hindrance to Japan's diplomacy (interview with the author; Saionji 2012a: 99-100). ${ }^{15}$

\footnotetext{
12 公演終了後、世界の各メディアを通して「池田提言」の内容は全世界へと伝わり、大きな反響 を呼んだ。「光明日報」特派員記者であった劉徳有の報告を通して、中国政府は早い段階で、 「池田提言」の内容を入手できた。周総理は「池田提言」を重視し、非常に高い評価を与えた。そ してその後、創価学会をさらに重要視するようになるのである。一九七○年一二月、周総理は、 訪中した菅沼正久氏との会見のさい「創価学会はどんな特徴があるのか」、「どういら日常活動を しているのか」な゙の質問を行い、創価学会について約三○分間にわたって語り合っている。

${ }^{13}$ Lín Lìyùn worked closely with Zhōu.

14 そんな状況でしたから、当時は日中国交正常化を主張するだけでも、あらゆる避難・攻撃を覚 悟なければならなかった。私はジャーナリストとして親中派の政治家を数多く取材していますが、 彼らは当時を振り返って、「親中派であるといらだけで右翼から攻撃されたりして、大変な時期だ った」と異口同音に語っていました。

15 十九六八年九月十一、一二日に東京で開かれた「日米安全保障協議」の内容があからになり ました。そこには日本の外務省首脳が、協議の三日前に発表された名誉会長の『日中提言』を強 く非難する様子が記録されていました。「池田会長の最近の言明は中国に対して、ひどく誤まっ た期待を高めさせることになった」などといら発言がなされていたのです。
} 
The fact that the Self-Defence Forces were allowed to march down Peace Boulevard in Hiroshima to protest for patriotism (from between 1965 to 1975; see Zwigenberg 2015: 6) indicate that right-wing groups were tolerated - if not supported — by at least parts of the Japanese people. Ikeda would have known the potential threat to his own safety a proposal for normalisation would stir, and he would have considered the issue of Taiwan - including some few hundred Sōka Gakkai members there. The Sōka Gakkai organisation in Taiwan would come to experience governmental harassment until the late 1980s, with the police sometimes bursting in on Sōka Gakkai meetings (personal communication with the then Sōka Gakkai general director of Taiwan, July 8, 1997; see also Saionji 2012a: 100).

As a journalist stationed in Japan, Liú Déyǒu (J. Ryū Tokuyū) first heard about the proposal when he watched the news that evening but had to wait three days to read the full text in the Sōka Gakkai newspaper, the Seikyō Shinbun 聖教新聞. ${ }^{16} \mathrm{He}$ immediately felt that this was important but knew how difficult it would be to write about it when all news media in China was criticising Japan for recently consolidating the treaty they had with Taiwan (Déyǒu cited in Kŏng and Jì 2006: 26). Yet, it was published in full three months later by the People's Daily Overseas Japan Monthly (December 1968) (ibid.). ${ }^{17}$ Liú Déyǒu observed that everyone in China took note of the address to the Japanese government not to ignore the 710 million Chinese people (ibid.). To envision and promote communalities beyond the immediate political circumstances and the competing political positionings must have seemed naïve at best. Still, it was the beginning of a different kind of student and youth movements that would call for friendship and youth exchange as the key to peace. Ikeda maintained that this should be based upon Japan's recognition of its imperialism into China, and urged Japan to correct its self-righteousness attitude that he saw dominating the Japanese government's approach to China, as well as left-right oppositional politics in their battle for legitimacy. In Ikeda's words:

When we encounter people from those countries who have suffered from Japanese occupation such as China, we must have a correct historical view. We have to know the correct history and begin to understand the pains and sorrows of the Chinese people. By doing so, we will come to reflect deeply as Japanese citizens. Words of apology come forth as a matter of course. I stress the importance of this point. We can build trust only when our conscience and sincerity are communicated. When I talk to those in diplomatic service, I always stress that diplomatic relations between two nations start from mutual trust between people. Regardless of Japan's foreign policy, we must always value and cherish direct person to person connections with the people

\footnotetext{
${ }^{16}$ Ikeda 1968a.
}

${ }^{17}$ Ikeda 1968 b. 
of China and engage in diplomacy with sincerity (cited in Kŏng and Jì 2006: 60, my translation). ${ }^{18}$

Self-criticism of the hallowed actions taken by the Japanese militarist government under the concept of the emperor's divinity was the starting point for recognising the suffering caused to others by the institutionalised violence of Japanese imperialism. Without such self-reflection little trust could be built. However, Ikeda also presented an alternative vision, which was seen at the time as undesirable by both mainstream society and right-wing nationalists, who tended to present "Japan" as a moral community whose citizens ought to defend its honour. Importantly, Ikeda's was not a lone voice but was backed up by millions of people who also voiced their politics through support for Kōmeitō. Yet, Ikeda did not come from a position of political power. Unlike governments or political parties that may have felt compelled to sanction China's extremist Maoist policies in the face of widespread public opinion, and thereby voters' animosity towards China, Ikeda could (perhaps more so) afford to project his vision and belief that the situation was not necessarily fixed, but could change when mindsets would change. No one, of course, could have known that in fact change was underway. As is now known, the American government would embark on secret talks with China that would lead to normalisation of ties and improve geopolitical relations for decades to come.

"In March 1970, Mr Matsumura Kenzō who was already 87 years of age entrusted the important task of promoting Sino-Japanese friendship to President Ikeda," said Vice President Huáng Shìmíng of the CJFA and Lǐ Déān 李徳安 who was then Tōkyō correspondent of the Xinhua News Agency (Xīnhuáshè 新華社). Although Matsumura asked Ikeda himself to go to China, Ikeda recommended they ask Kōmeitō, which as a political party would be in a position to negotiate a treaty. Thus, at the recommendation of Matsumura, Kōmeitō visited China in June 1971, and announced a joint statement with the CJFA. "During this visit, Premier Zhōu entrusted the Kōmeitō with five principles for normalisation of Sino-Japanese diplomacy," added Huáng. During their third trip to China in July 1972, Kōmeitō "was able to assume

\footnotetext{
18 (池田氏)特に中国などのように、日本に支配され、辛酸をなめてきた国の人と接する場合には、 その歴史を正しく認識しなければならない。(と述べている。)まずは、歴史を正しく認識し、中国 の人々が受けた、痛み、苦しみを知ることから始める。そうすれば、日本人として反省の念も起き てくる。当然のこととして、謝罪の言葉も出る。この点が重要である。(と強調している。)なぜなら ば、その時初めて相手が、こちらの人間としての良心、誠実さを知って、そして信頼が生まれてく るからである。(また外交に携わる者に対しても、) 国と国との外交といっても、すべて人間同士の 信頼から始まる。だから私たちは、日本の国が、どういら政策をとろうが、中国の人たちとの人間 性と人間性の触れ合いを常に大切にし、人間としての誠意ある外交をしていかなければならない。 （と、誠意ある外交を強調している。）
} 
the responsibility of liaison of the normalisation of Sino-Japanese diplomatic relations" (cited in Kǒng and Jì 2006: 68). ${ }^{19}$

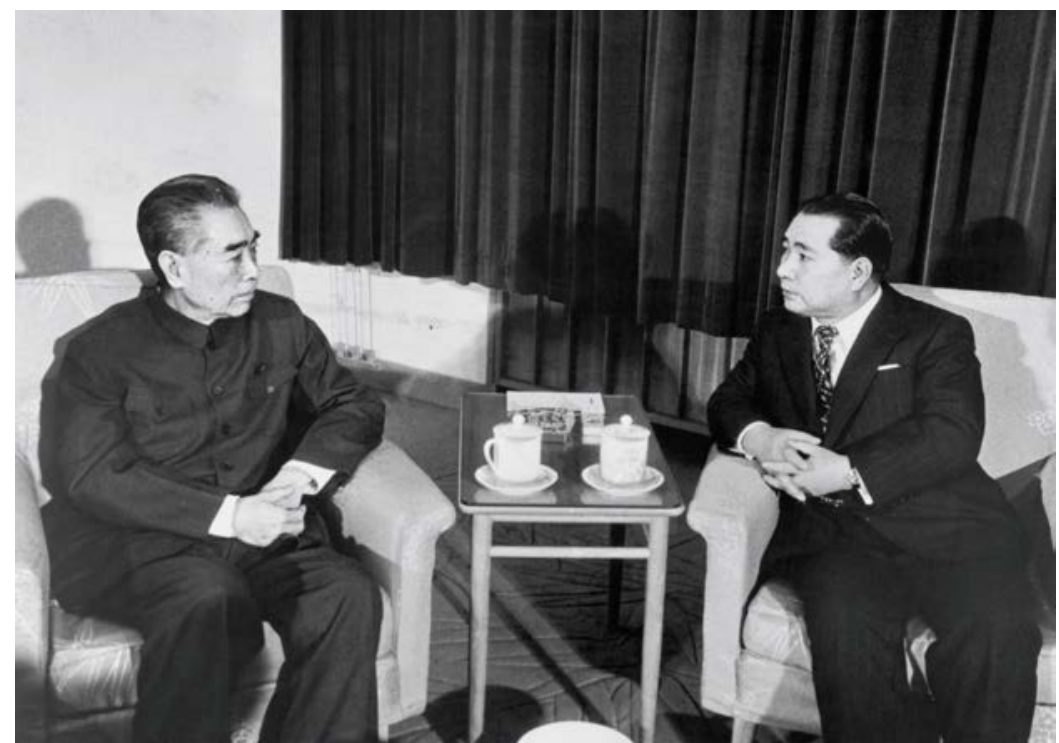

Figure 3: Zhōu Ēnlái and Ikeda Daisaku meeting in 1974 (Copyright permission received by Sōka Gakkai).

Within two months of the formation of Tanaka Kakuei's 田中角榮 (1918-1993) cabinet in July 1972, "Kōmeitō laid a path for the normalisation of diplomatic relations with China" Huáng wrote (ibid. 3). ${ }^{20}$

The party's official visit to China was realised because of President Ikeda's proposal in 1968 [...]. He was the first individual who had made a public appeal for the restoration of China's seat in the UN. When we negotiated with Kōmeitō, they had already included this item together with the US withdrawal of armed forces from Taiwan and the Taiwan Strait in addition to the three principles that China had previously put forward (Ieshige Akioka cited in Kŏng and Jì 2006: 106 , my translation). ${ }^{21}$

19 七○年三月、八十七歳の高齢の松村謙三氏は中日友好推進という重任を池田会長に託した。 池田会長は松村氏に公明党を推薦し、その重任を具体的に引き受けた。松村氏の推薦のもと、 七一年六月、公明党代表団は第一次訪中を実現し、「中日友好協会代表団と日本公明党訪中 団連合声明」の発表という具体的な成果をあげ、中日国交正常化の「復交五原則」を周総理から 託され、その後の中日両国政府間の交渉に路標を樹立させた。

20 七二年七月、公明党代表団は第三次訪中をし、さらに中日政府のパイプ役を果たした。

21 彼らが正式に訪中できたのは、池田先生の六八年の講演があったからです。[...]いちばん初 めに、民衆を前に国連における中国の議席回復を正式にアピールしたのが池田先生だったので す。ですから、公明党が私たちと交渉したとき、中国側の中日国交正常化三原則以外に、国連 
Thus when Zhōu first met with the Kōmeitō delegates (on June 28, 1971), relayed Akioka Ieshige 秋岡家栄 (b. 1925), who was Běijīng correspondent for the Asahi Shinbun in the early 1970s, his first words reportedly were to convey a message to President Ikeda, elaborating on how he regarded the Kōmeitō delegation as representatives of a party that had been established by Ikeda (ibid.). ${ }^{22}$ The perception of close affinity between Ikeda and Kōmeitō clearly worked in Kōmeitō's favour. Meanwhile in Japan, an issue over freedom of speech (genron mondai 言論問題) had erupted in 1969/1970 that would come to dominate perceptions of the Sōka Gakkai-Kōmeitō relationship. This was brought about by the publication of Fujiwara Hirotatsu's book Sōka Gakkai o kiru [Cut off Sōka Gakkai] (1969), which heavily criticised this close relationship, while simultaneously representing the organisation as both communist and fascist. Yet, Zhōu seemed to have perceived the proximity of Ikeda to Kōmeitō as what made the party trustworthy, as Ikeda had shown himself to be committed to Sino-Japanese friendship.

The Fujiwara incident of 1970 dominated public opinion in Japan about the two organisations (Fisker-Nielsen 2012: 61). A well-known political commentator and academic at the time, Fujiwara accused Sōka Gakkai of curtailing freedom of expression, which had come about as Sōka Gakkai leaders had met with Fujiwara to point out the errors his book contained, and some members who worked in book stores or for newspapers had expressed their disagreement with the sale of the book. Fujiwara accused Sōka Gakkai of both fascism and communism, as well as for being a danger to democracy in Japan. While the book contained many errors, Ikeda nevertheless apologised at the 33rd Headquarters General Meeting in 1970 for the way some members had reacted to its publication, stressing his support for freedom of expression as the foundation for democracy and human rights. Despite this domestic situation, Zhōu seemed unperturbed by the fact that just as he was approaching to work with Sōka Gakkai and Kōmeitō they had become public spectacle and subject to widespread criticism in Japan. "I have been paying attention to your views and calls since the party's establishment. I appreciate the Kōmeitō's recent statements regarding issues on SinoJapanese relations. We highly value your views. We invited you because of such reasons," Ieshige Akioka reported from the meeting (cited in Kŏng and Jì 2006: 106). ${ }^{23}$

での中国の議席回復、アメリカ軍の台湾および台湾海峡地区からの撤収をはっきりと提起してい ました。

22 そして周総理が公明党代表団と会見したときの、最初の一言が、池田会長への伝言であった。 (七○年代初期、朝日新聞社の北京特派員であった秋岡家茂氏は「(池田)会長の使者として、 周総理は、公明党代表団を見ていました」と語っている。(公明党は池田先生が創立した政党で す。)

23 公明党が設立されてから、皆さんの主張に注目してきました。公明党は最近、日中関係の問 題について、大変よい意見を発表しておられる。私たちも、高く評価しております。このたび、私 たちが皆さんをお招きしたのも、こういらところから出発しています。 
In retrospect, Ikeda's aim did not seem to be about the propagation of Nichiren doctrines in China in a direct way. However, it presented Ikeda's wider interpretation of Nichiren Buddhism as being about intention and behaviour that could go beyond specific doctrines and instead see "Buddhist" behaviour as consisting of creating personal connection and friendship at a particularly significant time of geopolitical crisis and as a way to move forward amidst oppositional power politics. This "friendship" approach was the beginning of hundreds of group exchanges between Sōka Gakkai youth members and their Chinese counterparts - which still continues today, half a century later. Ever since, thousands of Chinese exchange students have studied at Sōka University in Japan, and their counterparts have gone to study in China. The first of these groups of students came to the newly established Sōka University in 1975. They were also the first Chinese students to study in Japan in the post-war period.

When Ikeda went to China in May of 1974 upon an official invitation from the CJFA, a number of the current leadership in Sōka Gakkai, such as the then Sōka Gakkai International (SGI) Woman's leader Asano Kayoko 浅野加世子 (b. 1943) and the current Sōka Gakkai President Harada Minoru 原田稔 (b. 1941), joined him as part of the delegation (personal interview with Asano Kayoko on July 1, 2015). Ikeda went again a few months later, this time to meet Zhōu, who was very ill and died soon thereafter (Saionji 2012a). Ikeda has visited several times since then, including a trip in 1990, when he went with no less than 300 SGI representatives at, yet again, another contentious time of international isolation after the Tiānānmén Square incident. Numerous other delegations and exchanges, cultural performances, and exhibitions have continued yearly. For example, in June 2015, when this research first began, groups of Sōka Gakkai youth representatives visited Peking University, Nankai University, Yanbien University, and the National Museum to exchange views with various Chinese counterparts. A few months before the visit in 2015, and only a few years after the height of diplomatic tension over the Senkaku/Diàoyú Island dispute, the CPAFFC and the Shanghai Media \& Entertainment Group staged in Okinawa a successful Japanese premiere of the dance drama Crested Ibis, or Toki 朱鷺, produced in collaboration with the Sōka Gakkai affiliated Min-on Music Association (Minshu ongaku kyōkai 民主音楽協会).

The Min-On ${ }^{24}$ is today a major partner of CPAFFC. Toki was also performed in Tōkyō as one of the many events held by the China-Japan Friendship Association to

\footnotetext{
${ }^{24}$ Min-On means "the people's music" or "music for the people," an association founded by Ikeda in 1963. As a non-profit, independent, nondenominational organisation, Min-On promotes global exchange of musical culture. It has brought some of the world's top-performing artists to Japan, aiming to unite people through cultural performances that are seen to bring people together and thereby indirectly contribute to building peace through music and performing arts. Supported by more than a million sustaining members today throughout Japan, it has sponsored thousands of musicians and performing artists from more than one-hundred countries, who have performed in more than 300 cities across Japan, as well as hundreds of Japanese artists to perform abroad. Toki was
} 
commemorate the fortieth anniversary since normalisation. Toki was about friendship between the two countries based on a true story of reviving the crested ibis in conservation areas in Niigata and the Sado Island after they were found to still exist in Shănxī, China, in 1981. In October 2014, over 1,000 guests from the fields of politics, economics, culture, and education, including ambassadors from twenty-five countries, came to watch this dance drama production, Crested Ibis. This included, among others, Princess Akiko of Mikasa 涁子女王 (b. 1981) and Prime Minister Abe Shinzō of Japan, Li Xiăolín 李小林 (b. 1953), the Chairperson of the CPAFFC and then Ambassador H. E. Chéng Yǒnghuá 程永华 (b. 1945) of China (who was among the first group of six exchange students sent by China in 1975 to study at Sōka University).

The effect of a cultural performance in transforming attitudes towards the "Other" is difficult to measure and may be temporary, and only reports from participants testify to their positive experience. News reports also pointed out: "Incidentally, it was apparently only when Abe mentioned he had enjoyed the Chinese ballet 'Crested Ibis' that Xí Jìníng's expression softened into a smile but for a brief moment. The ballet was also shown in Niigata Prefecture. Perhaps, the ibis, a symbol serving as a bridge for Sino-Japanese friendship, may serve to bring hearts together" (Niigata Nippō 新 潟日報 2014: editorial page). ${ }^{25}$ The Yomiuri Shinbun more boldly concluded: “The Chinese ballet 'Crested Ibis,' which had as its theme the ibis, the symbol of SinoJapanese friendship, served as the impetus for the realisation of the formal meeting between the two heads of state" (Yomiuri Shinbun 2014: 1). ${ }^{26}$

As mentioned, Sōka University, established in 1971, was the first university in Japan to receive Chinese students sent by the PRC in the post-war period. Six came in 1975, one of whom was Chéng Yǒnghuá, who were to become the Chinese ambassador to Japan during the recent years of tension (2010-2019). During research on these relationships in June 2015, I attended an informal reunion dinner with one of the Chinese students, now in her sixties, who was visiting Japan. Some twenty-five former Japanese Sōka University students from that time, who had studied Chinese then, were present. They fondly recalled their time together forty years ago. Most were then in some form working in jobs related to China in some capacity, and some of their children were then studying Chinese — as did their parents. Their stories included recalling

one such performance. Min-On was granted the status of incorporated foundation in 1965. Today, the organisation has completed international cultural exchanges with 110 countries and regions (as of 2020) including those in Africa, Asia, Oceania, Europe, Middle East, and North, South, and Central America. An official collaboration for international cultural exchange between the Agency for Cultural Affair, the Ministry of Education, and Min-On began in 2019.

25 ところで、会談で安部氏が中国の舞劇「朱鷺」を観賞したことを話すと、その時だけは習氏の顔 がほころんだといら。本県でも上演された劇だ。日中友好のシンボル、眯け橋であるトキが心を合 わせる一助となるのではないか。

26 日中友好のシンボルであるトキをテーマにした＜舞劇「朱鷺」>は、首脳会議実現のキーワー ドの一つだった。 
Chinese students growing their own vegetables on campus (which consisted then mostly of large fields) and how Ikeda attended the home cooked dinner they made from these vegetables. Ikeda sent a long message to this dinner, jokingly saying that when he first heard they were gathering, he had wanted to pay for their dinner; but then remembered that of course they were all adults now, to which they all laughed as they remembered fondly their days as poor students, when Ikeda had personally looked after them at Sōka University, both as their guarantor in Japan and through personal support for them. No one had imagined at the time that their small actions and friendships would become part of a Sino-Japanese history.

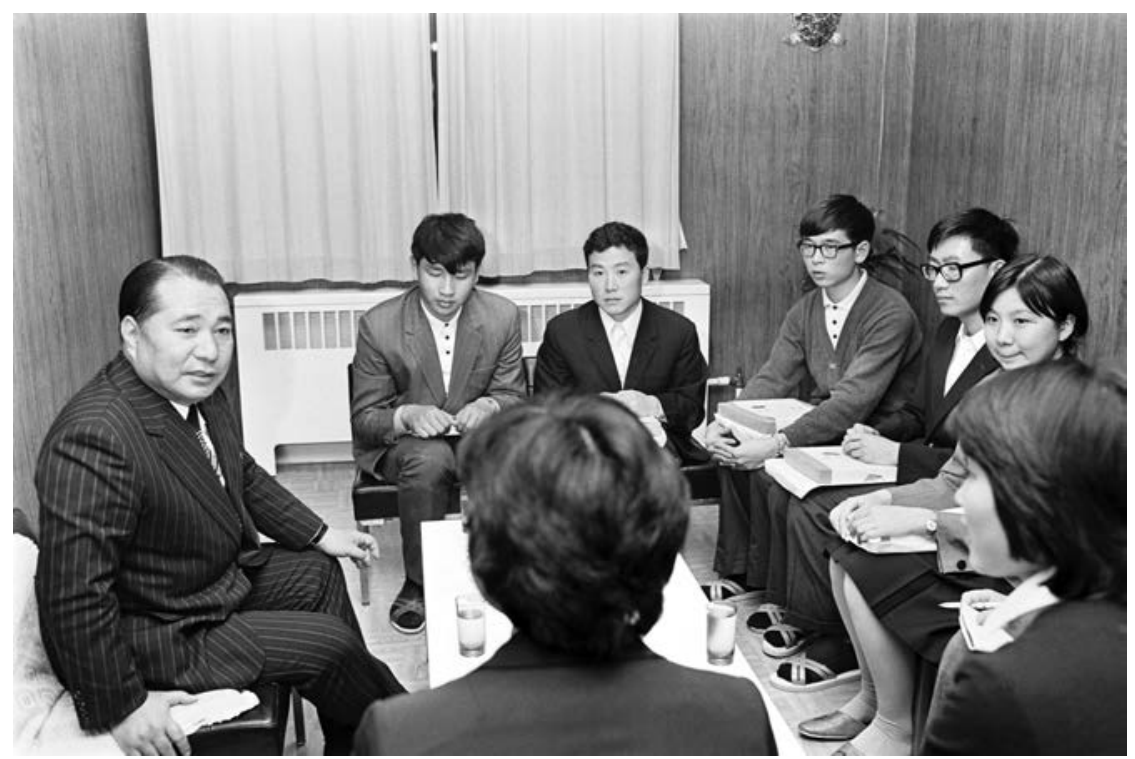

Figure 4: Ikeda Daisaku meeting with Chinese students in 1976 (Copyright permission received by Sōka Gakkai).

Today Sōka Gakkai consists of a grassroots network that reaches across Japanese communities with a membership of estimated eight to ten million (eight million households), and about 1.5 million across Asia. Ikeda's "philosophy of peace" (Urbain 2010) is today widely researched by academics in China. The over one-hundred academic awards he has received from Chinese universities, and the more than twenty research centres established at different Chinese universities dedicated to studying his ideas about peace, highlight how Ikeda's approach to peace and good relations between Japan and China has been officially accepted. ${ }^{27}$ Ikeda continued to emphasise youth exchange as ways to establish links between people, and thousands of Sōka

${ }^{27}$ See Appendix. 
Gakkai Japanese youths also came to study Chinese or Chinese Studies. Critical awareness of Japan's imperial history is high among the Sōka Gakkai membership, which is a history that continues to be central to Japan's relations with China. Saionji suggests:

I feel that Sōka Gakkai's role as a people's power is extremely significant as it has continued without interruption endeavouring to connect the two countries through friendly exchanges. Sōka Gakkai has consistently promoted people-to-people exchange, and youth exchange in particular. I believe such an endeavour derives from Sōka Gakkai Honorary President Ikeda's proposal for the normalisation of Japan-China relations. While it is easy to do something good for a short period of time, it is difficult to continue. Under President Ikeda's leadership, Sōka Gakkai has been committed for many years to promoting exchanges between the two countries (Saionji $2012 b) .^{28}$

Saionji, who was a journalist when Ikeda first visited China in 1974, met with Ikeda after his meeting with Zhōu Ēnlái, where they ended up talking for over three hours. Saionji later came to head the first Confucius Institute in Japan, at Kōgakuin University. Also, as the vice president of the JCFA, he explains that the organisation is a much less significant one today than at the time when organisations required mediation or introduction to reach people in China (personal interview on July 2, 2015). Saionji emphasises that the wider significance in Ikeda's approach to China lies in the attitude towards China to be found among Sōka Gakkai members.

The impression that I get when I am in contact with Sōka Gakkai members is that the spirit of fostering Sino-Japanese friendship penetrates the men and women of all ages [...]. It is quite significant that the passion for Sino-Japanese friendship runs through this enormous organisation of ordinary people that holds a prominent position in Japanese society. I think the Sōka Gakkai's role will be increasingly important in the establishment of eternal friendship between the two countries (Saionji 2012b). ${ }^{29}$

28 このような状況で、日中の友好関係を決して断絶させることなく、結び続けていく民衆の勢力と しての創価学会の役割は、非常に重要であると思います。学会の皆さんは、一貫して民間交流、 特に青年交流を推進してこられました。その原点は、池田名誉会長の日中国交正常化提言でし よう。短期的に良いことをするのは簡単です。しかし、継続することは困難です。創価学会は、名 誉会長のリーダーシップのもと、長年にわたつて交流を続けてこられました。

29 私が創価学会の皆さんとお会いして感銘を受けるのは、老若男女、全ての世代で日中友好を 大事にしていこうといら精神が浸透していることです。(中略)このように、日本社会の重要な位置 を占める巨大な民衆団体に日中友好の熱い感情が満ちあふれている意義は大変に大きい。万 年にわたる両国の友好へ、創価学会の果たす役割は、これからますます重要になることと思いま 于。 


\section{Conclusion}

Today, in a textbook for history teachers at junior high and high schools (Jiàoshi cānkăo zīliào 教師参考資料, chapter 5) in China, Ikeda is introduced as:

Japan's Sōka Gakkai President Ikeda issued a proposal for the normalisation of diplomatic relations between Japan and China presenting the Japanese government and people with a reasonable direction and basic process for its realisation at a time when relations between the two countries were extremely difficult (cited in Saionji 2012a: 68). ${ }^{30}$

The extent of this history should not be overstated, and may appear negligible compared to economic and political interests at play amidst an intense geopolitical relationship that continues today. Still, the cross-border approach for reaching out as "people's diplomacy" was not insignificant either. Many in Japan perceived this to be a fraught relationship between "politics" and "religion," as an intersection between two incommensurate realms. Those constituted as religious groups in Japan may be subject to typical assumptions about having other ulterior motives going beyond a stated desire to foster good relations, as so conspicuously pointed out by Fujiwara (1969) who saw Sōka Gakkai as a supporter of both communism and fascism. Looking at this book today, the way it so significantly shaped public opinion in the following years illuminates Hardacre's (2003) argument that perceptions of religious groups deeply intertwine with media representations of them, rather than providing particular insight into Sōka Gakkai itself. Furthermore, the social activities of groups of people in non-official capacities, as Sōka Gakkai members were, coupled with their generally low social status of mostly poor people at the time, as well as with their ability to organise grassroots networks capable of intercepting as a historical force, may have been particularly alarming in a society where civic groups operating outside the immediate control of the state have been traditionally viewed with suspicion and suppressed (Garon 1997).

This article has explored a socially active Buddhist group, backed up by a political party, which posed a challenge to the normative social order of Japanese society rooted in a statecraft that built upon the binaries of left-right ideologies and deeply ideological assumptions about what constitutes secular-religious divides (Horie 2018). It succeeded in transposing some national interests and identity politics that dominated Japan's relations and dealings with China at the time, in line with what Kawamura argued that was the desire for convergence between the categories of ethnicity and the state that stems from the period around World War I (Kawamura 1937 discussed in

\footnotetext{
30 中国の高中歴史教材『教師参考資料』第 5 章「外交を打開する新局面」のなかで、「日本創価 学会会長の池田大作氏は、中日関係が困難な状況に陥った時、『日中国交正常化提言』を発表 し、日本政府と人民に中日関係正常化の正しい方向と基本的プロセスを提示した」と、その歴史 的な功績が紹介されている。
} 
Doak 2011). The state in its multiple form is an instrument of political power. In the first instance, it is able to claim control over a specific territory; its elite players are able to organise and represent their legitimacy to rule under the banner of national symbolic unity and sense of belonging. The organisation of the state is usually distinguished through perceptions of sovereignty (Doak 2011: 540) legitimated through notions of collective national embodiment of its "people" as represented in the actions of its leaders. The idea of connecting through a shared sense of common humanity attempted to override this kind of national identity politics, and, in the case discussed here, may still prove significant in times of geopolitical crises.

Based on seeking some form of commonality and "friendship" to transcend national or ideological identity politics, the notion that a different mindset, attitude, and consciousness may seem naïve in our vastly complex world of power politics. Yet, the 1968 declaration for normalisation intercepted a different vision and attitude into geopolitics and transpired into a long-term commitment to friendship with China on the part of Sōka Gakkai as a civil society - still resonating in Kōmeitō's foreign policy approach to China in 2018. This is due to a now half a century long history of trust-building that has been Ikeda's approach to peacebuilding, whereby even amidst opposing stakeholders some common ground can be sought. It goes without saying that this is never a final project nor always very successful when looking at this from the perspective of today's increasingly complex geopolitical situation.

Ikeda may be seen (both positively and negatively) as a friend to China, who instituted a history and a historical narrative that stress the cultural heritage Japan owes to China, while self-critiquing Japan's past military aggression. This emerged out of an era that was coming to terms with Japanese imperialism and the rise of Communism. Regular right-wing trucks with mega loudspeakers circulating Sōka University during big events or on national holidays continue to remind us that some groups in Japan starkly disagree with acknowledging Japan's imperial history. Such "sonic activism" has been a steady feature of post-war Japanese society, and a group like the Dai Nippon Aikokutō 大日本愛国党, founded in 1951, has been organised around the principle of anti-Communism (Smith 2013). Sōka Gakkai's legacy of "friendship" with China today is considered a positive approach to peacebuilding among Sōka Gakkai members across the organisation, although this is complicated by the current militarisation and rising economic power of China that differs from previous decades. Ikeda's stance towards China may be hard to appreciate or accept by those who point primarily to the critiques that can be levelled towards the history of the CCP. Ikeda expressed little public criticism towards the CCP despite its contentious Maoist policies at the time, seemingly aware that a typological historical narrative also provides poor representation of what was a more complex picture that equally obscured the many internal tensions and differences among political players, including Zhōu Ēnlái.

Indeed, Ikeda's approach has been to praise the admirable aspects of Chinese long cultural traditions, ideas, and past idealised actions of leaders who are seen as having 
worked for the welfare of people - the way that Zhōu Ēnlái himself is usually portrayed. However, the lack of direct critique and focus on ideals does contain a more subtle and implicit criticism of those who did not and do not live up to such leadership ideals. It is a different form of critique that avoids a blanket approach towards the collective idea of "China," or towards the CCP, as if it were one historical body of unified ideas and actions of its leaders, which is also inaccurate. This resonates with cultural dynamics of "giving face" publicly, not simply as a hypocritical performance, but as a sign of respect whereby more direct interaction can be had elsewhere. Instead of critiquing "China" as a collective whole - after all, China is many different things - it avoided the default position that so easily turned in times of crisis a whole people into the symbolic "Other," or enemy. This Self-Other binary logic that underpin identity politics and tend to amplify the hostility between groups of people can become a powerful mobilising force, either for elite political purposes or grassroots movements as seen both in China and in Japan-in 1968, in 2012, or today.

Ikeda's approach in the 1960s refused to let Máo Zédōng, or the Cultural Revolution, be the sole representative of what constituted "China" - or let the politics of the day frame how one ought to act. It is not surprising that these actions were represented as a public "nuisance" at best, and a threat to democracy at worst (Fujiwara 1969). However, by pointing to the long cultural indebtedness and shared history Japan has with China, Ikeda sought to avoid the effect of short-sightedness of the immediate political circumstances that were playing out against a mindset of arrogance towards China that predominated in Japan, at a time when many Chinese people were themselves undoubtedly struggling with the Cultural Revolution. In this way, he aimed to create a space of conviviality that could open up dialogue amidst otherwise extreme power struggles and geopolitical tensions.

While some may have seen this as a compromise that served Sōka Gakkai's own proselytising agenda, this critique has not exactly materialised. Sōka Gakkai's relative success as an international Buddhist movement arguably was set by the kind of leadership discussed here, which aimed to find ways to pursue spaces of conviviality to bridge and connect otherwise diverse sets of people and interests, as well as an alternative way to create common ground. This is not a mindset easily captured by a sociological or political analysis; it is perhaps more easily seen by some form of comparison. As mentioned, 1968 was a watershed year for student protest movements in Japan. This encompassed some twenty per cent of the student population, i.e., some four per cent of the nation's late-teens and early twenty-something, estimated to be around 300,000. Oguma (2015) shows how, despite its seeming progressive aims, the movement was often apolitical, inward-facing, and moralistic, engaged in continuous self-negation and displaying retrograde attitudes towards women and minorities. A much less well-known student and youth movement began in the same year, when the Buddhist leader Ikeda, himself forty years old at the time, publicly called for JapanChina normalisation, which made him a figure of interest to Premier Zhōu Ēnlái. It 
also instigated a long-term commitment and movement for creating good relations based on international youth exchange. This youth movement has proven to be an enduring feature that continues today as seen also during the COVID-19 pandemic (Fisker-Nielsen 2020).

Ikeda's approach of seeking to find human commonality despite the many other political challenges present was rooted in his interpretation of Nichiren Buddhist practice as something that is not separated from everyday affairs and individual behaviour. This article explored an alternative social force, which, with the backing of a political party, did represent political power but paradoxically challenged the normative understanding of what politics and religion were assumed to be at the time. Ikeda's longterm view that allowed a focus on interrelations and common human connections tried to foster friendship within a political field dominated by more immediate political positioning and competition for power. This may seem an out of place gesture, but it demonstrated, at least to his followers, his interpretation of Nichiren Buddhism as being primarily about how and with what intention one acts towards others. Thus, this was not a movement that began as a way to legitimate a specific "religious" doctrinealthough perhaps the organisation itself - but to legitimate an attitude towards others that seeks to transcend Self and Other as a binary structure, even the nationalist SelfOther binary of identity politics. The extent to and the manner in which this attitude transpires in future Sōka Gakkai groups, who try to emulate this history, remains an empirical question.

\section{APPENDIX}

Academic Institutes in China established to research the philosophy of Daisaku Ikeda

\begin{tabular}{|c|c|c|c|}
\hline & University & Research Institute & Established \\
\hline 1 & $\begin{array}{c}\text { 北京大学 (Peking Uni- } \\
\text { versity) }\end{array}$ & $\begin{array}{c}\text { 池田大作研究会 (Ikeda Daisaku Research } \\
\text { Association) C. 池田大作研究会 }\end{array}$ & $\begin{array}{c}\text { December } \\
2001\end{array}$ \\
\hline 2 & $\begin{array}{c}\text { 湖南師範大学 (Hunan } \\
\text { Normal University) }\end{array}$ & $\begin{array}{c}\text { 池田大作研究所 (Ikeda Daisaku Research } \\
\text { Institute) C. 池田大作研究所 }\end{array}$ & $\begin{array}{c}\text { December } \\
2001\end{array}$ \\
\hline 3 & $\begin{array}{c}\text { 安徽大学 (Anhui Uni- } \\
\text { versity) }\end{array}$ & $\begin{array}{c}\text { 池田大作研究会 (Ikeda Daisku Research } \\
\text { Association) C. 池田大作研究会 }\end{array}$ & $\begin{array}{l}\text { March } \\
2003\end{array}$ \\
\hline 4 & $\begin{array}{c}\text { 肇慶学院 (Zaoping } \\
\text { University) }\end{array}$ & $\begin{array}{c}\text { 池田大作研究所 (Ikeda Daisaku Research } \\
\text { Institute) C.池田大作研究所 }\end{array}$ & $\begin{array}{l}\text { March } \\
2004\end{array}$ \\
\hline 5 & $\begin{array}{c}\text { 上海杉達学院 (Sanda } \\
\text { University) }\end{array}$ & $\begin{array}{c}\text { 池田大作教育思想研究センター } \\
\text { (Research Centre for the Educational Philoso- } \\
\text { phy of Ikeda Daisaku) }\end{array}$ & $\begin{array}{c}\text { August } \\
2004\end{array}$ \\
\hline
\end{tabular}




\begin{tabular}{|c|c|c|c|}
\hline & & C.池田大作教育思想研究中心 & \\
\hline 6 & $\begin{array}{c}\text { 中山大学 (Sun Yat-sen } \\
\text { University) }\end{array}$ & $\begin{array}{c}\text { 池田大作とアジア教育研究センター } \\
\text { (The Ikeda Daisaku and Asian Education Re- } \\
\text { search Centre) } \\
\text { C. 池田大作亚洲教育研究中心 }\end{array}$ & $\begin{array}{l}\text { May } \\
2005\end{array}$ \\
\hline 7 & $\begin{array}{c}\text { 華中師範大学 } \\
\text { (Central China Normal } \\
\text { University) } \\
\end{array}$ & $\begin{array}{c}\text { 池田大作研究所 (Ikeda Daisaku Research } \\
\text { Institute) C. 池田大作研究所 }\end{array}$ & $\begin{array}{l}\text { June } \\
2005\end{array}$ \\
\hline 8 & $\begin{array}{c}\text { 遼寧師範大学 } \\
\text { (Liaoning Normal Uni- } \\
\text { versity) }\end{array}$ & $\begin{array}{c}\text { 池田大作平和文化研究所 } \\
\text { (The Ikeda Daisaku Research Institute for a } \\
\text { Culture of Peace) C. 池田大作和平文化研究 } \\
\text { 所 }\end{array}$ & $\begin{array}{l}\text { January } \\
2006\end{array}$ \\
\hline 9 & $\begin{array}{c}\text { 北京連合大学旅游学 } \\
\text { 院 } \\
\text { (Tourism College of } \\
\text { Beijing Union Univer- } \\
\text { sity) } \\
\end{array}$ & $\begin{array}{c}\text { 池田大作時習会 (Ikeda Daisaku Research } \\
\text { Association) C. 池田大作时习会 }\end{array}$ & $\begin{array}{r}\text { July } \\
2006\end{array}$ \\
\hline 10 & $\begin{array}{c}\text { 武漢大学 (Wuhan Uni- } \\
\text { versity) } \\
\end{array}$ & $\begin{array}{c}\text { 池田大作研究所 (Ikeda Daisaku Research } \\
\text { Institute) C. 池田大作研究所 } \\
\end{array}$ & $\begin{array}{l}\text { October } \\
2006\end{array}$ \\
\hline 11 & $\begin{array}{c}\text { 湖南大学 (Hunan Uni- } \\
\text { versity) }\end{array}$ & $\begin{array}{c}\text { 池田大作研究センター (Ikeda Daisaku Rese- } \\
\text { arch Centre) C. 池田大作研究中心 }\end{array}$ & $\begin{array}{l}\text { October } \\
2006\end{array}$ \\
\hline 12 & $\begin{array}{l}\text { 広西師範大学 (Gua- } \\
\text { nguxi Normal Univer- } \\
\text { sity) }\end{array}$ & $\begin{array}{c}\text { 池田大作教育思想研究所 } \\
\text { (The Educational Philosophy of Ikeda Dai- } \\
\text { saku Research Institute) } \\
\text { C. 池田大作教育思想研究所 } \\
\end{array}$ & $\begin{array}{l}\text { December } \\
2006\end{array}$ \\
\hline 13 & $\begin{array}{l}\text { 東北師範大学 (Northe- } \\
\text { ast Normal University) }\end{array}$ & $\begin{array}{c}\text { 池田大作哲学研究所 } \\
\text { (Research Institute on the Philosophy of } \\
\text { Ikeda Daisaku) } \\
\text { C. 池田大作哲学研究中心 } \\
\end{array}$ & $\begin{array}{l}\text { May } \\
2007\end{array}$ \\
\hline 14 & $\begin{array}{c}\text { 広東省社会科学院 } \\
\text { (Guangdong Academy } \\
\text { of Social Science) }\end{array}$ & $\begin{array}{c}\text { 広東池田大作研究会 } \\
\text { (Ikeda Daisaku Research Association in } \\
\text { Guăngdōng) C. 广东池田大作研究会 }\end{array}$ & $\begin{array}{l}\text { May } \\
2008\end{array}$ \\
\hline 15 & $\begin{array}{l}\text { 華南師範大学 (South } \\
\text { China Normal Univer- } \\
\text { sity) }\end{array}$ & $\begin{array}{c}\text { 池田大作先生教育思想研究所 } \\
\text { (Research Centre for the Educational Philoso- } \\
\text { phy of Ikeda Daisaku) } \\
\text { C. 池田大作先生教育思想研究所 } \\
\end{array}$ & $\begin{array}{l}\text { May } \\
2008\end{array}$ \\
\hline 16 & $\begin{array}{c}\text { 陝西師範大学 (Shaanxi } \\
\text { Normal University) }\end{array}$ & $\begin{array}{c}\text { 池田大作·香峯子研究センター } \\
\text { (Ikeda Dasiaku and Kaneko Research Centre) } \\
\text { C. 池田大作·香峰子研究中心 }\end{array}$ & $\begin{array}{l}\text { September } \\
2008\end{array}$ \\
\hline
\end{tabular}




\begin{tabular}{|c|c|c|c|}
\hline 17 & $\begin{array}{c}\text { 韶関学院 (Shaoguan } \\
\text { University) }\end{array}$ & $\begin{array}{c}\text { 池田大作思想研究所 (The Research Insti- } \\
\text { tute for Ikeda Daisaku Philosophy) } \\
\text { C. 池田大作思想研究所 }\end{array}$ & $\begin{array}{l}\text { November } \\
2008\end{array}$ \\
\hline 18 & $\begin{array}{c}\text { 広東外語外貿大学 } \\
\text { (Guangdong University } \\
\text { of Foreign Studies) } \\
\end{array}$ & $\begin{array}{c}\text { 池田大作思想研究所 } \\
\text { (The Research Institute for Ikeda Daisaku } \\
\text { Philosophy) C. 池田大作思想研究所 } \\
\end{array}$ & $\begin{array}{l}\text { January } \\
2009\end{array}$ \\
\hline 19 & $\begin{array}{c}\text { 嘉応学院 (Jiaying Uni- } \\
\text { versity) }\end{array}$ & $\begin{array}{c}\text { 池田大作文化哲学研究所 (The Cultural } \\
\text { Philosophy of Ikeda Daisaku Research Insti- } \\
\text { tute) C. 池田大作文化哲学研究所 }\end{array}$ & $\begin{array}{c}\text { January } \\
2009\end{array}$ \\
\hline 20 & $\begin{array}{l}\text { 上海師範大学 (Shang- } \\
\text { hai Normal University) }\end{array}$ & $\begin{array}{c}\text { 池田大作思想研究センター } \\
\text { (The Research Centre for Ikeda Daisaku Phi- } \\
\text { losophy) C. 池田大作思想研究中心 }\end{array}$ & $\begin{array}{l}\text { October } \\
2009\end{array}$ \\
\hline 21 & $\begin{array}{c}\text { 仲愷農業工程学院 } \\
\text { (Zhongkai University of } \\
\text { Agriculture and Engine- } \\
\text { ering) }\end{array}$ & $\begin{array}{c}\text { 廖承志・池田大作研究センター } \\
\text { (Liào Chéngzhì ・ Ikeda Daisaku Research In- } \\
\text { stitute) C. 廖承志·池田大作研究中心 }\end{array}$ & $\begin{array}{c}\text { November } \\
2010\end{array}$ \\
\hline 22 & $\begin{array}{c}\text { 西安培華学院 (Xi’an } \\
\text { Peihua University) }\end{array}$ & $\begin{array}{c}\text { 池田大作・香峯子研究センター } \\
\text { (Ikeda Daisaku and Kaneko Research Centre) } \\
\text { C. 池田大作・香峰子研究中心 } \\
\end{array}$ & $\begin{array}{l}\text { September } \\
2011\end{array}$ \\
\hline 23 & $\begin{array}{l}\text { 大連工業大学 (Dalian } \\
\text { Polytechnic University) }\end{array}$ & $\begin{array}{c}\text { 池田大作思想研究所 } \\
\text { (The Research Institute for Ikeda Daisaku } \\
\text { Philosophy) C. 池田大作思想研究所 }\end{array}$ & $\begin{array}{l}\text { September } \\
2011\end{array}$ \\
\hline 24 & $\begin{array}{c}\text { 貴州大学 (Guizhou } \\
\text { University) }\end{array}$ & $\begin{array}{c}\text { 池田大作哲学研究所 } \\
\text { (The Research Institute for Ikeda Daisaku } \\
\text { Philosophy) C. 池田大作哲学研究所 }\end{array}$ & $\begin{array}{l}\text { January } \\
2012\end{array}$ \\
\hline 25 & $\begin{array}{c}\text { 紹興文理学院 (Shao- } \\
\text { xing University) }\end{array}$ & $\begin{array}{c}\text { 魯迅·池田大作研究所 } \\
\text { (The Lǔ Xùn-Ikeda Daisaku Research Insti- } \\
\text { tute) C. 鲁迅与池田大作研究中心 }\end{array}$ & $\begin{array}{l}\text { March } \\
2012\end{array}$ \\
\hline 26 & $\begin{array}{c}\text { 渤海大学 (Bohai Uni- } \\
\text { versity) }\end{array}$ & $\begin{array}{l}\text { 池田大作中日友好思想研究所 (The China- } \\
\text { Japan Friendship Philosophy of Ikeda Dai- } \\
\text { saku Research Institute) } \\
\text { C. 池田大作中日友好思想研究所 }\end{array}$ & $\begin{array}{l}\text { September } \\
2012\end{array}$ \\
\hline 27 & $\begin{array}{c}\text { 井岡山大学 (Jing- } \\
\text { gangshan University) }\end{array}$ & $\begin{array}{c}\text { 池田大作研究所 } \\
\text { (The Ikeda Daisaku Research Institute) } \\
\text { C. 池田大作研究所 }\end{array}$ & $\begin{array}{c}\text { October } \\
2012\end{array}$ \\
\hline 28 & $\begin{array}{c}\text { 北京師範大学 (Beijing } \\
\text { Normal University) }\end{array}$ & $\begin{array}{c}\text { 池田大作平和教育研究センター } \\
\text { (Ikeda Daisaku Research Centre on the Edu- } \\
\text { cation for Peace) } \\
\text { C. 池田大作和平教育研究中心 }\end{array}$ & $\begin{array}{l}\text { December } \\
2012\end{array}$ \\
\hline
\end{tabular}




\begin{tabular}{|c|c|c|c|}
\hline 29 & $\begin{array}{c}\text { 華東師範大学 (East } \\
\text { China Normal Univer- } \\
\text { sity) }\end{array}$ & $\begin{array}{c}\text { 池田大作社会教育研究センター } \\
\text { (The Ikeda Daisaku Research Centre for So- } \\
\text { cial Education) } \\
\text { C. 池田大作社会教育研究中心 }\end{array}$ & $\begin{array}{c}\text { November } \\
2013\end{array}$ \\
\hline 30 & $\begin{array}{c}\text { 復旦大学 (Fudan Uni- } \\
\text { versity) }\end{array}$ & $\begin{array}{c}\text { 池田大作思想研究センター } \\
\text { (The Research Centre for Ikeda Daisaku Phi- } \\
\text { losophy) C. 池田大作思想研究中心 }\end{array}$ & $\begin{array}{c}\text { November } \\
2013\end{array}$ \\
\hline 31 & $\begin{array}{c}\text { 大連芸術学院 (Dalian } \\
\text { Art College) }\end{array}$ & $\begin{array}{c}\text { 池田大作教育思想研究所 } \\
\text { (The Research Institute for the Educational } \\
\text { Philosophy of Ikeda Daisaku) } \\
\text { C. 池田大作教育思想研究所 }\end{array}$ & $\begin{array}{c}\text { December } \\
2013\end{array}$ \\
\hline 32 & $\begin{array}{l}\text { 南京理工大学 (Nanjing } \\
\text { University of Science } \\
\text { and Technology) }\end{array}$ & $\begin{array}{c}\text { 池田大作思想研究室 } \\
\text { (The Philosophy of Ikeda Daisaku Research } \\
\text { Department) } \\
\text { C. 池田大作思想研究室 } \\
\end{array}$ & $\begin{array}{l}\text { October } \\
2014\end{array}$ \\
\hline 33 & $\begin{array}{l}\text { 佛山科学技術学院 } \\
\text { (Foshan University) }\end{array}$ & $\begin{array}{c}\text { 池田大作研究所 } \\
\text { (The Ikeda Daisaku Research Institute) } \\
\text { C. 池田大作思想研究所 }\end{array}$ & $\begin{array}{c}\text { December } \\
2014\end{array}$ \\
\hline 34 & $\begin{array}{c}\text { 中山大学南方学院 } \\
\text { (Zhongshan University } \\
\text { Southern College) }\end{array}$ & $\begin{array}{c}\text { 国際教養教育・池田大作研究所 } \\
\text { (The Education for International Studies - } \\
\text { Ikeda Daisaku Research Institute) } \\
\text { C. 国际通识教育与池田大作研究所 }\end{array}$ & $\begin{array}{c}\text { November } \\
2016\end{array}$ \\
\hline 35 & $\begin{array}{c}\text { 蘇州大学 (Soochow } \\
\text { University) }\end{array}$ & $\begin{array}{c}\text { 池田大作中日友好思想研究会 } \\
\text { (The China-Japan Friendship Philosophy of } \\
\text { Ikeda Daisaku Research Association) } \\
\text { C. 池田大作中日友好思想研究会 } \\
\end{array}$ & $\begin{array}{l}\text { January } \\
2017\end{array}$ \\
\hline 36 & $\begin{array}{c}\text { 大連外国語大学 (Da- } \\
\text { lian University of For- } \\
\text { eign Languages) }\end{array}$ & $\begin{array}{c}\text { 池田大作研究所 } \\
\text { (Ikeda Daisaku Research Institute) } \\
\text { C. 池田大作研究所 } \\
\end{array}$ & $\begin{array}{c}\text { December } \\
2017\end{array}$ \\
\hline 37 & $\begin{array}{l}\text { 浙江越秀外国語学院 } \\
\text { (Zhejiang Yuexiu Uni- } \\
\text { versity of Foreign Lan- } \\
\text { guages) } \\
\end{array}$ & $\begin{array}{c}\text { 周恩来・池田大作研究センター } \\
\text { (Zhōu Ēnlái-Ikeda Daisaku Research Centre) } \\
\text { C. 周恩來一池田大作研究中心 }\end{array}$ & $\begin{array}{l}\text { June } \\
2019\end{array}$ \\
\hline 38 & $\begin{array}{c}\text { 大連海事大学 (Dalian } \\
\text { Maritime University) }\end{array}$ & $\begin{array}{c}\text { 池田大作研究センター } \\
\text { (Ikeda Daisaku Research Centre) } \\
\text { C. 池田大作研究中心 } \\
\end{array}$ & $\begin{array}{l}\text { July } \\
2019\end{array}$ \\
\hline 39 & $\begin{array}{c}\text { 厦門大学 (Xiamen } \\
\text { University) }\end{array}$ & $\begin{array}{c}\text { 池田大作思想研究センター } \\
\text { (The Research Centre for the Philosophy of } \\
\text { Ikeda Daisaku) } \\
\text { C. 池田大作思想研究中心 } \\
\end{array}$ & $\begin{array}{l}\text { July } \\
2019\end{array}$ \\
\hline
\end{tabular}




\begin{tabular}{|c|c|c|c|}
\hline 40 & $\begin{array}{c}\text { 河北大学 (Hebei Uni- } \\
\text { versity) }\end{array}$ & $\begin{array}{c}\text { 池田大作研究所 } \\
\text { (Ikeda Daisaku Research Institute) } \\
\text { C. 池田大作王蒙研究中心 }\end{array}$ & $\begin{array}{c}\text { October } \\
2019\end{array}$ \\
\hline 41 & $\begin{array}{c}\text { 池田大作王蒙研究センター } \\
\text { 貴州民族大学 (Guiz- } \\
\text { hou Minzu University) }\end{array}$ & $\begin{array}{c}\text { (Ikeda Daisaku-Wáng Méng Reseach Centre) } \\
\text { C. 池田大作王蒙研究中心 }\end{array}$ & $\begin{array}{c}\text { October } \\
2019\end{array}$ \\
\hline 42 & $\begin{array}{c}\text { 長春師範大学 (Chang- } \\
\text { chun Normal Univer- } \\
\text { sity) }\end{array}$ & $\begin{array}{c}\text { 池田大作文化研究所 } \\
\text { (The Ikeda Daisaku Culture Research Centre) } \\
\text { C. 池田大作文化研究所 }\end{array}$ & $\begin{array}{c}\text { November } \\
2019\end{array}$ \\
\hline
\end{tabular}

$\begin{array}{ll}\text { ABBREVIATIONS } \\ \text { CCP } & \text { Chinese Communist Party } \\ \text { CJFA } & \text { China-Japan Friendship Association } \\ \text { CPFA } & \text { China-Japan Friendship Association } \\ \text { CPAFFC } & \text { Chinese People's Association for Friendship with Foreign Countries } \\ \text { DPJ } & \text { Democratic Party of Japan } \\ \text { JCFA } & \text { Japan-China Friendship Association } \\ \text { JCP } & \text { Japanese Communist Party } \\ \text { JSP } & \text { Japanese Socialist Party } \\ \text { LDP } & \text { Liberal Democratic Party } \\ \text { PRC } & \text { People's Republic of China } \\ \text { ROC } & \text { Republic of China } \\ \text { SCAP } & \text { Supreme Commander of the Allied Powers } \\ \text { SGI } & \text { Sōka Gakkai International } \\ \text { WND } & \text { The Writings of Nichiren Daishonin }\end{array}$

\section{REFERENCES}

AFP with Bloomberg. 2013. "Japan's Abe Sends Peace Envoy to China.” The Sydney Morning Herald, January 25. Online http://www.smh.com.au/world/japans-abe-sends-peace-envoy-tochina-20130125-2dbqw.html (accessed: January 12, 2016).

Anderson, Benedict. 1983. Imagined Communities: Reflections of the Origin and Spread of Nationalism. London and New York: Verso.

Beckford, James A. 2003. Social Theory and Religion. Cambridge: Cambridge University Press.

Buhk, Alexander. 2020. These Islands are Ours. Stanford: Stanford University Press.

Chan, Yeeshan. 2011. Abandoned Japanese in Postwar Manchuria: The Lives of War Orphans and Wives in Two Countries. London: Routledge.

Chi, Madeline. 1980. "Ts' aoJu-Lin (1876-1966): His Japanese Connections.” In Akira Iriye, ed., The Chinese and the Japanese: Essays in Political and Cultural Interactions. Princeton:

Princeton University Press, pp. 140-160. 
Doak, Kevin. 2011. "State and Nation in Twentieth-Century Japan: Toward an Interpretive Framework." Japan Forum, 23 (4), pp. 531-555.

Dolce, Lucia. 2015. "The Practice of Religion in Japan Exploration of the State of the Field." In James D. Babb, ed., The SAGE Handbook of Modern Japanese Studies. London: SAGE, pp. $33-62$.

Dower, John W. 1990. “The Useful War.” Daedalus, 119 (3), pp. 49-70.

Dower, John W. and Hirata Tetsuo. 2007. "Japan's Red Purge: Lessons from a Saga of Suppression of Free Speech and Thought." Asia-Pacific Journal: Japan Focus, 5 (7), Article ID 2462.

Duus, Peter, Ramon H. Myers, and Mar R. Peattie. 1989. The Japanese Informal Empire in China 1895-1937. Princeton: Princeton University Press.

Fisker-Nielsen, Anne Mette. 2012. Religion and Politics in Contemporary Japan: Soka Gakkai Youth and Kōmeitō. London and New York: Routledge.

Fisker-Nielsen, Anne Mette. 2016. "Has Kōmeitō Abandoned its Principles? Public Percpetion of the Party's Role in Security Legislation Debates." The Asia-Pacific Journal: Japan Focus, 14 (21), No. 3, Article ID 4976.

Fisker-Nielsen, Anne Mette. 2018. "Sōka Gakkai.” In Lukas Pokorny and Franz Winter, eds., Handbook of East Asian New Religious Movements. Leiden and Boston: Brill, pp. 109-127.

Fisker-Nielsen, Anne Mette. 2020. "The Response of Soka Gakkai to the COVID-19 Pandemic: Personhood, Interiority, and a Civil Society in Crisis Mode.” The Journal of CESNUR, 4, pp. $25-48$.

Fitzgerald, Timothy. 2000. The Ideology of Religious Studies. Oxford: Oxford University Press.

Fogel, Joshua. 2015. Between China and Japan: The Writings of Joshua Fogel. Leiden and Boston: Brill.

Fujiwara, Hirotatsu. 1969. Sōka Gakkai wo kiru [Cut off Sōka Gakkai]. Tokyo: Nisshin Hodo Co.

Garon, Sheldon. 1997. Moulding Japanese Minds: The State in Everyday Life. Princeton: Princeton University Press.

Gao, Wenqian. 2007. Zhou Enlai: The Last Perfect Revolutionary. Philadelphia: PublicAffairs.

Gebert, Andrew. 2004. “Makiguchi Tsunesaburō: Chi no kanōsei e no shin 牧口恒三郎: 知の可 能性への信 [Makiguchi Tsunesaburō: Faith in the Possibilities of Knowledge].” M.A. Thesis, Waseda University 早稲田大学, Tōkyō 東京.

Goulah, Jason and Andrew Gebert. 2014. Tsunesaburo Makiguchi (1871-1944): Educational Philosophy in Context. London: Routledge.

Hardacre, Helen. 2003. “After Aum: Religion and Civil Society in Japan.” In Frank J. Schwartz and Susan J. Pharr, eds., The State of Civil Society in Japan. Cambridge: Cambridge University Press, pp. 135-153.

Hirata, Keiko. 2002. Civil Society in Japan: The Growing Influence of NGOs over Tokyo's Aid and Development Policy. New York: Palgrave Macmillan.

Hoffman, Reto. 2020. "What's Left of the Right: Nabeyama Sadachika and Anti-communism in Transwar Japan, 1930-1960.” The Journal of Asian Studies, 79 (2), pp. 403-427.

Horii, Mitsutoshi. 2018. The Category 'Religion' in Contemporary Japan: Shūkyō and Temple Buddhism. New York: Palgrave Macmillan.

Ijiri, Hidenori. 1990. "Sino-Japanese Controversy since the 1972 Diplomatic Normalisation." China Quarterly, 124, pp. 639-661.

Ikeda, Daisaku. 1968a. “「日中正常化への」[A Proposal for Sino-Japanese Normalisation].” Seikyō Shinbun 聖教新聞, September 10. Tōkyō 東京: Seikyō Shinbun 聖教新聞, pp. 4-5.

Ikeda, Daisaku. 1968b. “「日中正常化への」[A Proposal for Sino-Japanese Normalisation].” Asia Magazine, December Issue. Tōkyō 東京: Asia Magazine, pp. 47-54. 
Ikeda, Daisaku. 1968c [2013]. Proposal for the Normalisation of Sino-Japanese Relations. Hong Kong: Sōka Gakkai International of Hong Kong, 8 September [2013 English and Chinese Translation].

Ikeda, Daisaku. 1969. “A Proposal on China Issue: My Opinion-View on Communist China: The Paths of Japan and China Towards World Peace." The Economic Salon (January Issue). Tokyo, Japan, pp. 30-41.

Ikeda, Daisaku. 1974. Selected Speeches and Writings. Tokyo: Sōka Gakkai.

Ikeda, Daisaku. 2004. A Piece of Mirror and Other Essays. Malaysia: Sōka Gakkai Malaysia.

Ikeda, Daisaku. 2006. "A Power to Resist the Currents of History.” The Japan Times, May 11, pp. 11-13. Online https://www.japantimes.co.jp/opinion/2006/05/11/commentary/world-commentary/a-power-to-resist-the-currents-of-history/ (accessed: September 8, 2020).

Ikeda, Daisaku. 2012. The Opening of the Eyes. Santa Monica, CA: World Tribune Press. [English translation].

Ikeda, Daisaku, Saito, Katsuji, and Masaaki Morinaka. 2003. The World of Nichiren Daishonin's Writings: A Discussion on Humanistic Religion. Volume 1. Malaysia: Sōka Gakkai Malaysia.

Illouz, Eva. 2007. Cold Intimacies: The Making of Emotional Capitalism. Cambridge: Polity.

Iriye, Akira. 1996. "Chinese-Japanese Relations 1945-1990.” In Christopher Howe, ed., China and Japan: History, Trends and Prospects. Oxford: Oxford University Press, pp. 46-59.

Isomae, Jun'ichi 磯前順一. 2003. Kindai Nihon no shūkyō-gensetsu to sono keifu 近代日本の宗 教一言説とその系譜 [Modern Japanese Religion: Discourse and Its Genealogy]. Tōkyō 東京: Iwanami Shoten 岩波書店. [English translation: Isomae 2014.]

Isomae, Jun'ichi. 2014. Religious Discourse in Modern Japan: Religion, State and Shinto. Leiden and Boston: Brill

Ito, Takao. 2009. "Reading Resistance: The Record of Tsunesaburo Makiguchi's Interrogation by Wartime Japan's 'Thought Police'.” Educational Studies, 45, pp. 133-145.

Itoh, Mayumi. 2010. Japanese War Orphans in Manchuria: Forgotten Victims of World War II. New York: Palgrave Macmillan.

Jain, Rajendra K. 1981. China and Japan 1949-1980. New Jersey: Humanities Press.

Josephson, Jason A. 2012. The Invention of Religion in Japan. Chicago: University of Chicago Press.

Katagiri, Nobuo 片桐伸夫. 1995. “Nitchū minkan kōryū 日中民間交流 [Japan-China Civil Exchange].” In Hiroshi Masuda 増田弘 and Sumio Hatano 波多野澄雄, eds., Ajia no naka no Nihon to Chūgoku - Yūkō to masatsu no gendaishi アジアのなかの日本と中国 一友好と摩擦 の現代史 [Japan and China Inside Asia: Modern History of Friendship and Friction). Tōkyō 東京: Yamakawa Shuppansha 山川出版社, pp. 268-288.

Kawamura, Matasuke. 1937. "Kokka.” In Suehiro Izutarō and Tanaka Kōrarō, eds., Hōritsugaku Jiten [Dictionary of Jurisprudence]. Tokyo: Iwanami Shoten, pp. 925-933.

Kohn, Hans. 1994. The Idea of Nationalism. New York: The Macmillan Company.

Koide, R. 2014. "Critical New Stage in Japan's Textbook Controversy." The Asia-Pacific Journal, 12 (13), Article ID 4101.

Kǒng, Fánfēng 孔繁豊, and Jì Yàguāng 紀亜光. 2006. Zhōu Ēnlái, Daisaku Ikeda to Nitchū Yūkō 周恩来, 池田第策と日中友好 [Zhōu Ēnlái, Daisaku Ikeda and Sino-Japanese Friendship]. Tōkyō 東京: Hakuteisha 白帝社.

Kuriyama, Yoshihiro. 1976. “A Japanese Maoist: Niijima Atsuyoshi.” Asian Survey, 16 (9), pp. 846-854.

Lee, Chae-jin. 1994. Zhou Enlai: The Early Years. Stanford: Stanford University Press.

Matsumura, Wendy. 2015. Limits to Okinawa: Japanese Capitalism, Living Labor, and Theorization of Community. Durham and London: Duke University Press. 
Min-On Music Association. Online: http://www.min-on.org/index.php/about-min-on/who-we-are (accessed: January 12, 2016).

Miyake, Akimasa 三宅明正. 1994. Redopāji to wa nanika: Nihon senryō no kage レッド・パージと は何か一日本占領の影 [What Was the Red Purge? In the Shade of Occupation of Japan]. Tōkyō 東京: Ōtsuki Shoten 大月書店.

Mōri, Kazuko 毛里和子 and Zhāng Yùnlǐng 張蘊嶺. 2004. Nitchū Kankei o do kachikusuru kaAjia no kyōsei to kyōryoku mesashite 日中関係をどう家畜するか一アジアの共生と協力めさし $\tau$ [How Can We Rebuild Japan-China Relations? Co-existence and Co-operation in Asia]. Tōkyō 東京: Iwanami Shoten 岩波書店.

Nichiren. 1999. The Writings of Nichiren Daishonin. Vol. 1. Tokyo: Sōka Gakkai.

Niigata nippō 新潟日報. 2014. “Abe Shusō to Shūshi: Kinchō Kanwa e Taiwa no Keizoku wo 安倍 首相と習氏:緊張緩和入対話の継続を [Prime Minister Abe and Mr Xi: Continuing Dialogue to Ease Tension].” November 12, editorial page.

Oguma, Eiji. 2015. "Japan's 1968: A Collective Reaction to Rapid Economic Growth in an Age of Turmoil.” The Asia Pacific Journal: Japan Focus, 13 (12), Article ID 4300.

Palmer, Arvin. 1971. Buddhist Politics: Japan's Clean Government Party. The Hague: Martinus Nijhoff.

Pekannen, Robert. 2004. "After the Development State: Civil Society in Japan.” Journal of East Asia Studies, 4 (3), pp. 363-388.

Saionji, Kazuteru 西園寺一晃. 2012a. Zhōu Énlái to Ikeda Daisaku no ichigo ichie 周恩来と池田 大作の一期一会 [The Once in a Lifetime Meeting between Zhōu Ēnlái and Daisaku Ikeda]. Tōkyō 東京: Ushio Shuppansha 潮出版社.

Saionji, Kasuteru 西園寺一晃. 2012b. “Saionji Kazuteru to intabyū 西園寺一晃とインタビュー [Interview with Saionji Kazuteru].” Seikyō Shinbun 聖教新聞. September 29, p. 3.

Smith, Nathanial M. 2013. "Facing the Nation: Sound, Fury, and Public Oratory among Japanese Right-wing Groups.” In Joseph D. Hankins and Carolyn S. Stevens, eds., Sound, Space and Sociality in Modern Japan. London and New York: Routledge, pp. 37-56.

Soeya, Yoshihide 添谷芳秀. 1996. Nihon gaikō to Chūgoku: 1945-1972 日本外交と中国 19451972 [Japanese Diplomacy and China: 1945-1972]. Tōkyō 東京: Keiō Tsūshin 慶応通信.

Sōka Gakkai - Nihon no Shinkō Shūkyōteki Seijidantai『創価学会一日本の新興宗教的政治団 体』[The Sōka Gakkai-A New Religious Political Organisation]. 1963. Běijīng 北京: Běijīng shìjiè zhīshì chūbănshè 北京世界知識出版社.

Spence, Jonathan D. 1999. The Search for Modern China. New York: W. W. Norton.

Spence, Jonathan D. 2009. "The Mystery of Zhou Enlai." Chinafile, May 28. Online: https://www.chinafile.com/library/nyrb-china-archive/mystery-zhou-enlai (accessed: September 10, 2020).

Suganama, Masahisa 菅沼正久. 1967. Bunka dai kakumei 文化大革命 [The Great Cultural Revolution]. Tōkyō 東京: San'ichi Shobō 三一書房.

Taira, Teemu. 2013. "Making Space for Discursive Study in Religious Studies." Religion, 43, pp. 26-45.

Takemine, Tsukusa. 2006. Japan's Development Aid to China: The Long Running Foreign Policy of Engagement. London: Routledge.

Tanaka, Akihiko. 1991. Nitchū kankei 1945-1990 日中関係 1945-1990 (Japan-China Relations 1945-1990). Tōkyō 東京: Tōkyō Daigaku Shuppankai 東京大学出版会.

Thomas, Jolyon Baraka. 2019. Faking Liberties: Religious Freedom in American-Occupied Japan. Chicago and London: The University of Chicago Press. 
Togo, Kazuhiko. 2012. “Japan's Territorial Problem.” The National Bureau of Asian Research: Commentary, May 12. Online: https://www.nbr.org/publication/japans-territorial-problem-thenorthern-territories-takeshima-and-the-senkaku-islands/ (accessed: March 14, 2021).

Tōyama, Kiyohiko 東山清彦 2014. "Dai196 kai kokkai shūgiin yosan iinkai dai11gō heisei 30 nen 2gatsu 14ka 第 196 回国会衆議院予算委員会第 11 号平成 30 年 2 月 14 日 [The 196th House of Representative Budget Committee February 14, 2018].” Online: https://kokkai.ndl.go.jp/\#/detail?minId=119605261X01120180214\&current=1 (accessed: August 10, 2020).

Tsang, Steve. 1994. “Target Zhou Enlai: The 'Kashmir Princess' Incident of 1955.” China Quarterly, 139, pp. 766-782.

Urbain, Olivier. 2010. Daisaku Ikeda's Philosophy of Peace: Dialogue, Transformation and Global Citizenship. London and New York: I. B. Taurus.

Vyas, Utpal. 2011. Soft Power in Japan-China Relations: State, Sub-State and Non-State Relations. London: Routledge.

Wáng, Mĩn. 王敏 2005. Hontō wa Nihon ni akogareru chūgokujin 本当は日本に憧れる中国人 [The Truth is that Chinese People Admire Japan]. Tōkyō 東京: PHP Kenkyūsho PHP 研究所.

Yomiuri Shinbun 読売新聞. 2014. “'Senkaku’ dakyō de kaidan jitsugen「尖閣」妥協で会談実現 [“Senkaku”: Talks Realise a Compromise].” November 11, p. 1.

Zwigenberg, Ran. 2015. "Entangled Memories: Israel, Japan and the Emergence of Global Memory Culture.” The Asia-Pacific Journal: Japan Focus, 13 (32), Article ID 4354. 